\title{
DARIVANJE VODE U OBREDNO- MITOLOŠKOJ INTERPRETACIJI: PRIMJER SLOVENSKO-HRVATSKE ZNANSTVENE SURADNJE
}

\author{
JELKA VINCE PALLUA \\ Institut društvenih znanosti Ivo Pilar \\ Marulićev trg 19, \\ HR - 10000 Zagreb, Hrvatska \\ jelka.vince@pilar.hr \\ orcid.org/0000-0002-4280-5857
}

\begin{abstract}
Ovaj rad nalazi se u otvorenom pristupu i može se distribuirati u skladu s odredbama licencije CC BY-NC-ND 4.0 HR
\end{abstract}

U prvom dijelu članka prikazuje se konkretan primjer znanstvene suradnje hrvatske znanstvenice dr. Jelke Radauš Ribarić i njezina slovenskog kolege i prijatelja akademika Milka Matičetova na temi nazivlja i simbolike narcisa. $\mathrm{Na}$ osnovi pronađene korespondencije iz 1977. godine razmatraju se njihova promišljanja zasnovana na jednakim etnološkim smjernicama toga doba. U najopsežnijoj cjelini naslovljenoj "Nova interpretacija teme" autorica nudi novu obredno-mitološku interpretaciju običajnih proljetnih praksi s izvorom, lipom i narcisama u Vodicama u sjevernoj Istri. Nekadašnji jurjevski ophod, očuvan tamo u obliku dječjeg folklora u proljetnom darivanju narcisama izvora i bogiča na lipi, interpretiran je kao odraz, ostatak (pra)slavenskog, ujedno i pretkršćanskog obreda. Nazivlje za narcise - jurjevke i Marijine palčke / Maričice - autorica tumači jednakim interpretativnim kontekstom.

Ključne riječi: obredno-mitološka interpretacija, praslavenska mitologija, lipa, kristijanizacija, Jurjevo, Jarilo, Juraj, Mara, darivanje vode, vrelo, narcise, Istra, Vodice, slovensko-hrvatska znanstvena suradnja

Na skupu na Filozofskom fakultetu održanom u povodu 90. obljetnice neprekinute nastave etnologije u Zagrebu 8. studenoga 2017. godine nije nedostajalo i drugih okruglih obljetnica - 80 godina života prof. Vitomira Belaja, emeritusa Filozofskog fakulteta. Vitomir Belaj bio je pročelnikom Odsjeka za etnologiju i za vrijeme moga, točno dvadesetogodišnjeg zaposlenja i sudjelovanja u nastavi na ovom odsjeku - od prosinca 1986. godine do prosinca 2006. kada sam s Odsjeka prešla u Institut društvenih znanosti Ivo Pilar na kojem sam dosad provela, i tu opet okrugli broj - deset godina. ${ }^{1}$

\footnotetext{
${ }^{1}$ Deset godina (sada već gotovo 12 godina) bilo je u vrijeme izlaganja na znanstvenom skupu 2017. godine.
} 
Nastavljajući "hodom kroz godine" želim istaknuti da sam 9. studenoga 2014. godine, točno tri godine prije ovoga slavljeničkog skupa u Zagrebu, zajedno s kolegicom Ljiljanom Dobrovšak održala referat "Treba li nam Srednja Europa?" na 13. vzporednicama med slovensko in hrvaško etnologijo u Dolenjskim Toplicama u Sloveniji. Skup je bio posvećen temi "Srednjeevropsko povezovanje etnologov in kulturnih antropologov kot izziv današnjemu času". Zanimljivo je da se kolege iz Italije, Austrije i Mađarske tada nisu odazvali na poziv, ali je izlagalo mnogo zainteresiranih slovenskih i hrvatskih etnologa koji su svi snažno istaknuli potrebu stručno-znanstvene suradnje među slovenskim i hrvatskim znanstvenicima. Poziv upućen i na slovensko-hrvatski skup 8. studenoga 2017. godine odraz je svijesti o nužnosti ne samo današnjeg umreženja nego i prisjećanja na nekadašnje različite strukovne veze - znanstvene upućenosti hrvatskih na slovenske istraživače i obratno.

\section{UVOD}

Na tom tragu (nakon I. Uvoda) u drugom dijelu ovog priloga (II. Korespondencija) predstavit ću plodnu znanstvenu povezanost Slovenije i Hrvatske na primjeru dvoje znanstvenika - jednoga slovenskog i jedne hrvatske znanstvenice, pasioniranih vrsnih istraživača. U trećem dijelu članka (III. Milko Matičetov o temi narcisa) kratko se iznose razmišljanja Milka Matičetova o postavljenoj temi u njegovu članku objavljenom 1979. godine, dvije godine nakon njihove korespondencije: "BEDENÍCE - Imena, pesniško in obredno izročilo o tem cvetju na Slovenskem in pri sosedih v hrvaški Istri". Traditiones - Acta Instituti ethnographiae Slovenorum, vol. 5-6, 1976-1977:277-300. U četvrtom, ujedno i najdužem dijelu ovoga rada (IV. Nova interpretacija teme) iznijet ću u konačnici svoju interpretaciju obredno-mitološkog aspekta ove teme.

Riječ je dakle o stručno-znanstvenoj korespondenciji² između Slovenca akademika Milka Matičetova, etnologa, kustosa Etnografskog muzeja u Ljubljani, i višega znanstvenog suradnika Inštituta za slovensko narodopisje u Ljubljani (10. rujna 1919. - 5. prosinca 2014.) i Hrvatice dr. Jelke Radauš Ribarić, ${ }^{3}$ etnologinje, dugogodišnje djelatnice i ravnateljice Etnografskog muzeja u Zagrebu (8. ožujka 1922. - 9. ožujka 2015.). Uvid u njihovu suradnju moguće je dobiti na osnovi zanimljive, žive i učestale korespondencije o istraživačkoj temi narcisa (hrv.) / bedenica (slov.) tijekom četiri mjeseca 1977. godine (od 24. lipnja do 24. listopada), dakle prije točno četrdeset godina od održavanja skupa

\footnotetext{
${ }^{2}$ Ta je korespondencija pohranjena u Etnografskom muzeju u Zagrebu (u kojem je J. Radauš Ribarić provela svoj radni vijek) kao dio donacije predane Muzeju (inv. br. EMZ O-JRR-956).

${ }^{3}$ U pismima Jelku Radauš Ribarić Milko Matičetov oslovljuje njezinim nadimkom Desa.
} 
u studenome 2017. u Zagrebu. Razmjena pisama između dvoje znanstvenika ilustracija je, rekla bih čak role model, izvrsne suradnje hrvatskih i slovenskih etnologa. Spomenuti znanstvenici bili su gotovo vršnjaci školovani na bliskim teorijsko-metodološkim etnološkim zasadama. Osim bliskosti na stručnom etnološkom planu, iz devet njihovih pisama moguće je iščitati i osobnu prijateljsku bliskost dvoje ljudi do kraja posvećenih svom poslu ne samo kao dužnosti nego i kao strasti i istinskom životnom pozivu. Njihova će suradnja biti prikazana osobito na primjeru Istre - područja na kojem se Slovenci i Hrvati dodiruju, tj. na kojem su stoljećima susjedi. Milko Matičetov ističe da je on sam "Kraševec in sosed Istranom in Čičem in Bezjakom" (pismo 2), a Jelka Radauš Ribarić kći je prof. Josipa Ribarića rođenog u Vodicama, selu na planinskom lancu Ćićarija tik uz granicu Istre i Slovenije, području koje je Matičetov, potaknut upravo suradnjom s hrvatskom kolegicom, uključio u svoja istraživanja. Matičetov izravno kaže: "moj ekskurz v vaša 'lovišča' ni bil odveč, je bil nujen za reševanje tudi slovenskih imen" (pismo 7).

Budući da je ovaj rad bio prilogom prošlogodišnjem skupu organiziranom u povodu 90. obljetnice neprekinute nastave etnologije u Zagrebu, a u kojoj je niz desetljeća sudjelovao Milovan Gavazzi, ${ }^{4}$ valja reći da se u njihovu dopisivanju na više mjesta spominje i Gavazzi o čijoj je pak korespondenciji u članku "Korespondencija Milovana Gavazzija u Hrvatskom državnom arhivu" 2005. godine pisao Mario Stipančević (2005). Među brojnim drugima, u tom su Stipančevićevu članku kao Gavazzijevi korespondenti spomenuti i Matičetov (135 pisama) i Radauš Ribarić (9 pisama). ${ }^{5}$

Već u naslovu spomenutoga vrijednog i opsežnog članka (1979.) Milko Matičetov, uz imena za narcise, najavljuje bavljenje pjesničkom i obrednom tradicijom vezanom uz narcise u Sloveniji i hrvatskom dijelu Istre. No, premda Matičetov na više mjesta u tom članku (str. 294, 296, 297, 299 - bilj. 38, 300) za sljedeći broj časopisa Traditiones obećaje objavu drugog dijela članka - Pjesnička i obredna tradicija uz narcise - taj dio, nažalost, nikada nije ugledao svjetlo dana.

\section{KORESPONDENCIJA}

Pred nama je, kako rekoh, poticajna i na više načina zanimljiva korespondencija u razdoblju od četiri mjeseca (od 24. lipnja do 24. listopada 1977.). Dopisivanje možemo pratiti na osnovi pet pisama Milka Matičetova i četiri pisma Jelke Radauš Ribarić. Plodna i poticajna suradnja razmjenom pisama započela je, kako možemo pročitati u prvom

\footnotetext{
${ }^{4}$ U pismu 8 Matičetov ga naziva "neutrudni Gavazzi" / neumorni Gavazzi.

${ }^{5}$ Svakako je ovaj manji broj pisama posljedica (i) činjenice da su Gavazzi i Radauš Ribarić živjeli u istom gradu, čak u istom kvartu - Gavazzi u Zvonimirovoj ulici, a Radauš Ribarić u neposrednoj blizini u Vojnovićevoj ulici u Zagrebu.
} 
pismu Jelke Radauš Ribarić, telefonskim upitom Milka Matičetova o nazivu za cvijet narcise u Istri nakon kojeg je uslijedilo pismo s hrvatske strane (pismo 1). Zbog osobite zanimljivosti, ali i navođenja nekih drugih imena hrvatskih i slovenskih znanstvenika (Milovan Gavazzi, Josip Milićević, Niko Bonifačić, Josip Ribarić, Jerko Bezić, Paola Gabrić, Ivan Šugar, Niko Kuret, Vilko Novak, Fran Erjavec, Emilijan Cevc itd.), što također upućuje na slovensko-hrvatsku suradnju - osnovnu nit skupa, navodim sva pisma in extenso. U suprotnom, mnogo bi toga bilo izostavljeno i nejasno.

\section{Pismo 1 (24. lipnja 1977.) - Jelka Radauš Ribarić}

Dragi Milko, odmah kako sam zaklopila telefon nakon tvoga poziva iz Ljubljane, otišla sam do police i uzela knjigu moga tate da ti izvadim podatak za "sugavicu". ${ }^{6}$ Ipak sam dobro zapamtila taj naziv za cvijet narcise za koji si me pitao. Dakle, citiram iz radnje moga oca:

sugati, sügan uz süglen, sisati. Cf. Pușcariu o.c. sub. sug (ar. smg. supšu, süptu), ir. sugu, supt, 'sisati', sugo-xi-ctum-ere: tal. suggere. U Liburniji je nepoznato, kod "Slovinaca"? K tomu sugovica f. 'sunovrat, narcisa' (tako nazvana jer biljka sadrži slatki sok koji djeca sišu.

(Ribarić, Josip, Razmještaj južnoslavenskih dijalekata na poluotoku Istri, Srpski dijalektološki zbornik, knj. IX, str. 195, Beograd, 1940. (Pușcariu: Wörterbuch der rumänischen Sprache, Heidelberg 1905.)

Toliko o samoj riječi, što si me zamolio da pronađem. Sjećam se međutim pripovijedanja moga oca, da su u proljeće svi obronci oko Vodica bili posve bijeli od sugavica, onako kako je po tome poznata Golica u Karavankama. Narod je brao cvijeće, zapravo po nekoliko cvjetova i bacao u vrelo žive vode, koje je iznad sela. Zbog tog nabacanog cvijeća znalo se sve vrelo zagaditi, ali običaj se održavao. Svatko tko je prolazio bacio bi nekoliko cvjetova u izvor. Ne znam da li se to još održava, odnosno kada je taj običaj eventualno zamro. Naravno da ću o tome pitati prvi put kad budem išla u Vodice, a ako što novo doznam, javit ću ti. Možda se može i vrelo fotografirati, ukoliko nije zatvoreno, kad je još moj otac kao student, tamo na prijelazu stoljeća, uredio da se voda dovede do samog sela. Drago mi je ako sam ti ovim podatkom pomogla u kakvom tvom istraživanju. Srdačno tebe i familiju pozdravlja vaša ... potpis $^{7}$

\footnotetext{
${ }^{6}$ Kako se vidi u njezinu navodu iz: Ribarić 1940 (a također i u Ribarić 2002:215), vodički lokalni naziv za narcisu je sügovica, ne sügavica. No ovdje ostavljam, kao i svuda drugdje, tekst u originalu.

7 Na kopijama pisama Jelke Radauš Ribarić pronađenim u njezinoj ostavštini nema, naravno, njezina potpisa. Zbog toga na svim takvim mjestima stavljam točkice uz napomenu "potpis".
} 


\section{Pismo 2 (20. srpnja 1977.) - Milko Matičetov}

Draga Desa! Ne zameri mi, da Te še enkrat nadlegujem v zvezi s sugovicami. Ker zdaj v pasjih dneh ni verjetno, da bi Te pot zanesla proti Čičariji, se vprašujem, ali nimaš morda kakega dobrega znanca, prijatelja, sorodnika v Vodicah, na katerega bi se mogla pismeno obrniti po informacijo o studencu, živi vodi, kamor so metali spomladi cvetje (z vprašanjem event. "zakaj" - kakor otroci smo radovedni in moramo biti radovedni, saj spada k našemu poklicu!), in še kako je studencu ime, čega pač ima. Sama si kriva, da si mi "dala bolho v kožuh", zdaj se praskam in še Tebe morim!

Ekipa naših muzealcev je na Mažuranićevem trgu, pripravlja nekakšno razstavo. Če jo pojdeš gledat, jim lahko ustno sporočiš, če imaš kaj zame. Posebej Fanči Šarfovi, s katero smo v stikih bolj kot $z$ drugimi.

Pa še nekaj: ali bi se dalo morda kje antikvarno stakniti delo, ki si mi ga zadnjič citirala, izpod peresa Tvojega rajnega očeta, o istrskih narečjih? Kot Kraševec in sosed Istranom in Čičem in Bezjakom etc. sem kajpada zainteresiran, da bi tudi sam imel to v svoji knjižnici.

\section{S prisrčnimi pozdravi od starega Milka}

P.S. Nemara veš, da našega soseda in prijatelja Perusinija ni več. Pred dobrim mescem smo se poslovili nepričakovano od njega zadnji Ce fastu, ki ga je uredil, izide še letos in naprosili so me za besedo o njegovem etnografskem delu. Misli na prispevek za "Traditiones" ki bojo post festum prinesle še nekaj zapoznelih lastovk!

\section{Pismo 3 (18. kolovoza 1977.) - Jelka Radauš Ribarić}

Dragi Milko, konačno ti, nakon prilično čekanja, šaljem podatke o običaju u Vodicama u Ćićariji, a u vezi Tvoga zanimanja za "sugovice". Molio si me da te podatke prikupim makar od nekog pismeno, ali ja nažalost u rodnom mjestu moga oca nemam više bliže rodbine, a niti znam nekoga tko bi mi poslao vjerodostojne podatke. Zato sam odlučila da tamo idem sama. Bila sam u Vodicama 3.8. - i dobro je da sam bila osobno. Mislim da će te ono što sam ispitala, i što ti "in extenso" šaljem, zadovoljiti, mene je oduševilo.

Dakle, ranije sam ti pisala o tome, da su u proljeće bacali sugovice u živo vrelo kraj sela i da se toga toliko nakupilo, da je svo vrelo bilo zagađeno (po pričanju moga oca).

U tvom pismu od 20.7. moliš me da pokušam doznati "zašto" su bacali cvijeće u vrelo i kako je vrelu ime.

Vrelo se zove "Studenac" i nalazi se u neposrednoj blizini sela, oko tri stotine koračaja (brojila sam) na zapad od vodičke župne crkve u smjeru prema Jelovicama. Nalazi se uz put, ali naokolo su polja, tu više nema seoskih zgrada. Ipak, to nije ona glavna, zidana cesta, nego put koji vodi u polje. To je vrelo žive vode, ali je između dva rata pod Italijom zazidano i pokrito betonom, a ostavljeno je korito za blago da pije. 
"Studenac je zvirna voda. Taj studenac se je zvirom čistia, svaku godinu. Sada ni več onako kako je bia, sada je pokrit s cementom. To je bia velik prostor kako jedna vela bačva i tri škaline su išle doli. To je bilo za blago i za robu ispirati i prati. Bilo je puno vode i teklo je van. Posli su zatvorili i načinili korito i tu blago pije" (Milka Ribarić - Skameničeva, rođ. Šverko).

Voda iz Studenca ne otiče nikuda, kraški je teren pa se izgubi. Kad su bile velike kiše su nastale mlake (Milka Ribarić - Skameničeva). Velje od Studenca dalje je, kadi se voda razlivala (Jelka Ribarić - Kalčova, rođ. Poropat).

I ja kad sam bila sada kod zazidanog Studenca teren naokolo je bio vlažan usprkos ljetne žege, znači vode tamo uvijek ima.

Što se samog običaja tiče doznala sam ovo: U proljeće, kad cvatu sugovice, uberu se tri cvijeta (po jednoj kazivačici sedam - Jela Ribarić - Baldinova) i bace se u vrelo, a uz njih i tri mala, mickina kamenčića. Bacilo in se samo jedanput u godini, kad se u vrijeme cvatnje prvi put prolazilo kraj Studenca. Kraj toga se ništa nije govorilo niti izgovaralo. Neki kažu da je to bio uglavnom dječji običaj (dob 12-13 godina), da su djeca kad su brala sugovice, bacila u Studenac nekoliko cvjetova kao dar, da se ne bi utopila (Jelka Ribarić - Kalčova). U Studenac su bacali samo sugovice, nikakvo drugo cvijeće. No, sugovice su se nosile i do jednog križa na Mlaki, tamo smo isto sugovice bogiču vrgli. To je bia tako kako jedan dar... (Mate Ribarić - Kalčov).

Pitajući, gdje se baš nalazio taj križ, konstatirala sam da nije stajao samostalno, nego je bio pričvršćen na jednu lipu (!) koja još i danas stoji udaljena oko pedeset koraka zapadno od Studenca, a koliko je stara svjedoči njena veličina. Opseg debla u visini od cca $1 \mathrm{~m}$ iznosi cca 4,5 m! Mjerila sam mojim sežnjevima. (Dvije, isto tako velike lipe stoje u blizini seoske crkve u smjeru ravno na zapad prema Studencu).

Interesirala sam se i o tome, da li su i na druga koja vrela bacali sugovice. Kažu da nisu. Na danskin potoku je isto zvirna voda, zdrava i pitna, ali nisu hitali sugovice (Milka Ribarić - Skaničeva). Za ostala sela (Dane, Jelovice nisu znali ništa reći, a ja nisam imala vremena da idem tamo na ispitivanje).

Stariji ljudi svi se još sjećaju da su bacali sugovice i kamenčiće u Studenac, jer je u njihovo djetinjsko i mladenačko doba još bilo vrelo otvoreno. Vrelo je pokrito prije 45-50 godina. Otada se taj običaj nije više mogao održavati. Muškarci, osobito oni srednje dobi, negiraju postojanje tog običaja (braća Josip i Miro Rupena - Juretinovi), ali se sjećaju da su kao djeca sugali sok od sugovica, i da su im od suganja znale doći kraste oko ustiju (Josip Rupena - Juretinov). Milka Ribarić - Skameničeva kaže da njoj nisu došle kraste jer se odmah ubrisala i pazili su da im ne dojde prah na usta (pelud). I današnji mladi još sišu stabljike sugovice (Nada Ribarić - Peckina). 
Kazivači:

Milka Ribarić - Skameničeva (rođ. Šverko), rođ. 1904. u Vodicama

Jela Ribarić - Baldinova, rođ. u Vodicama 1908. g.

Rude Ribarić - Toncin, rođ. u Vodicama 1897. g.

Jelka Ribarić - Kalčova (rođ. Poropat), rođ. u Vodicama 1910. g.

Mate Ribarić - Kalčov, rođ. u Vodicama 1907. g.

Jože (Josip) Rupena - Juretinov, rođ. oko 1917. u Vodicama, oko 60 godina

Miro Rupena - Juretinov, rođ. u Vodicama, oko 55 god.

Nada Ribarić - Peckina, rođ. u Vodicama 1964. god.

Dragi Milko, toliko o imenu, običaju, i "suganju". Obećajem ti još i fotografije Studenca i lipe, ali ih još nemam, jer su filmovi na razvijanju. U svakom slučaju čini mi se taj običaj još do nedavno sačuvanog vegetacijskog kulta (vrelo, lipa, cvijeće prvo proljetno cvijeće) u Ćićariji upravo senzacionalan. Bacanje kamenčića u vrelo nije li simpatička magija (neka se utopi kamen umjesto mene)? Magijski brojevi tri i sedam! Jednokratno darovanje cvijeća za napredak u cijeloj godini?

Kako se ja običajima ne bavim i mislim da je prekasno da se tome posvetim, prepuštam ti ove svoje "pabirke", ali kako se radi o mjestu mojih pređa, volila bih da ne ostanem anonimna. Puno uspjeha i srdačan pozdrav Tvoja stara ... potpis

\section{Pismo 4 (19. kolovoza 1977.) - Milko Matičetov}

Draga Desa! Malo si predaleč, če ne, bi gotovo slišala moj veseli vrisk, ko sem prebral Tvoje pismo! Juhuhuj! Vida je od nekod z balkona prišla vprašat, kaj je zdaj to, pa sem ji kar dal, naj prebere. Ker sem bil ravno namenjen na Akademijo, ko je prišel pismonoša s Tvojim dragocenim pismom, Ti zdajle iz inštituta kar takoj odgovarjam in se Ti prisrčno zahvaljujem!

Čudovite podatke bom kajpada takoj vpletel v sestavek o jurjevkah (delovni naslov, ki bom moral o njem temeljito premisliti, posebej tudi zaradi Tvojih vodiških odkritij). To se razume, da se ne bom krasil z "ljudskim" (tujim) perjem in bom navedel po potrebi celo Tvoje informatorje-/ke, kaj šele Tebe! Tvoj prispevek, se mi zdi, daje potrebno vezno gradivo med antičnimi pričevanji in današnjim sodobnim ljudskim izročilom, ki prav v Vodicah kaže neverjetno arhaično podobo, nepričakovano, enkratno. Čeprav sem že ekscerpiral ustrezno geslo pri Pauly-Wissowi, moram zdaj zaradi Vodic vzeti v roke še Roscherja in morda še kaj. Da vidim, kaj je ok. grške personifikacije jurjevk - sugovic medenic etc. - (Nárkyssos) takega, da bi se dalo koristno primerjati in da bi ne bila samo fantastika. No, boš že brala, kaj bom spletel v šopek, vsega tu ne morem povedati.

Posebej odhajata po pošti kot tiskovina dva separata, da se boš malo vadila $v$ 
italijanščini. Ob prispevku o ČAS-u, iz Gavazzijevega zbornika, mi prihaja na misel, da Te pocukam spet za prispevek v Kuretovem zborniku. Kako? Tudi v časopisu Ethnologia Slavica v Bratislavi so imeli toliko prispevkov, da niso mogli vseh spraviti v en letnik. Zato bo tudi v prihodnjem še nekaj člankov, ki so pa napovedani - z avtorjem in naslovom - že v tem prvem, iz katerega je separat. Lepo bi Te prosil, da bi če se le da že v tem letu 1977 napisala svoj obljubljeni prispevek, da bi ga mogli napovedati na koncu tega zbornika za 1978. Ne boš sama, ampak v dobri družbi (E. Cevc, J. Bezić, N. Bonifačić pa še ta in oni, ki mi ta hip ne pride na misel; rok za oddajo so zamudili za toliko, da jih nikakor ni moč vključiti, pa jih bomo na koncu ali na ovitku ali kakorkoli omenili, nje in njihove deleže.) Svoj prispevek iz Dolomitov, panoramo izročila tamkajšnjih Ladincev, pa Ti pošiljam zato, ker boš morda kaj vedela ali se spomnila iz svojih lektir o prekopavanju mrtvih. Ta navada se zdaj pojavlja (z jasnimi obrednimi znamenji oz. karakteristikami) podobno v krajih, kamor Slovani niso nikoli prišli, s tem pa postaja Gasparinijeva atribucija Slovanom vprašljiva. Čeprav se skromno umikaš, češ: "Ja se običajima ne bavim", vendar veliko veš in si marsikaj srečala na svojh popotovanjih, pa boš morda le kaj pripomnila. Pa tudi če nič, vendar verjamem, da si le vzameš kdajpakdaj toliko časa, da kaj prebereš tudi zunaj programa, za oddih ali iz radovednosti...

Željno, ampak potrpežljivo bom čakal fotografske priloge - studenca in lipe, na katero je bil pritrjen križ. Za to ne gori voda, kadar bo prišlo, bo dobro, saj za klišarno dajemo gradivo posebej.

Še enkrat najprisrčnejša hvala! Bodi mi zdrava in če bi Te pot zanesla v Ljubljano, glej, da se prikažeš v Langusovi 19! Tvoj stari in hvaležni Milko

\section{Pismo 5 (13. rujna 1977.) - Milko Matičetov}

Draga Desa! V nedeljo 11. tm. je bil prelep dan, ki sem ga izrabil za pot po sledovih domačih imen za narcise. Z Vido in Matejem (morali smo ga zbezati iz vojašnice v Ajdovščini, pa je šel še kako rad z nami na pot!). Oglašam se Ti da Ti povem, da sem od Podgorja ubral pot v Čičarijo, do 11 km oddaljenih Jelovic. Mikalo me je slišati, kako pravijo tam "moji" cvetki, ki je v Podgorju "mandalénka", v 2 km. oddaljenih Prapročah "mandaléna" itn. No, v Jelovicah ji pravijo smúgalica. Ker smo morali spet v Ajdovščino z našim vojakom in potem še $v$ Ljubljano, sem se lahko ustavil v Jelovicah samo četrt urice. Dovolj, da sem izvedel, da ne poznajo nič takega, kot si Ti našla v 5 km. oddaljenih Vodicah! Vsaj moški informatorji ne, ki so bili v gostilni pri Čendaku. Seveda bi me mikalo iti do jelóviškega "studenca" in dobiti kake starejše ženske, pa ni bilo časa. Vtis v ti prvi čički vasi je bil žalosten: hiše se podirajo, ker so ljudje zapustili domačo vas in odšli v svet. Gostilničar mi je kazal stari tip hiše z "velbom" iz kamna in pripovedoval, kako so $\vee$ preteklosti $\vee$ bližini zažgali celo vas (imena si nisem zapomnil), prebivalci sosednje 
vasi, ne kaka vojska od zunaj, da bi se polastili sveta, zemlje. Danes je zemlje, pašnikov, vsega na pretek, le ljudi ni, ki bi kmetovali, pasli, sirili etc. Etnografi tu lahko kaj naredimo, kako pomagamo? To sem se vpraševal, ko sem se s težkim srcem vračal iz Čičarije. Odgovora nisem našel. Sklenil sem, da se Ti bom oglasil in Te prisrčno pozdravil v imenu vseh treh udeležencev čičke ekskurzije! Da si mi zdrava! Milko

\section{Pismo 6 (17. listopada 1977.) - Jelka Radauš Ribarić}

Dragi Milko, ja sam Ti dužna pisamce još tamo od ljeta, kad sam dobila tvoj odgovor na građu što sam ti je poslala iz Ćićarije. Toliko sam se bila zagrijala za tvoj (meni nepoznati, ali naslućivani) problem, da sam iz literature u mojoj biblioteci odmah povadila neke podatke, dala in kopirati - i u pomanjkanju vremena pustila da do danas leže na radnom stolu. Razgovor s Paulom Gabrić, koju si zamolio da ti pribavi termine za narcise u Hrvatskoj, piknuo me da Ti se i ja javim. Naravno, u međuvremenu dobila sam i drugo Tvoje pismo, pisano nakon posjeta Jelovicama sa Matevžom - vojnikom (Bože, kako vrijeme leti!) i Vidom. No kod mene se u to vrijeme nakupilo poslova i problema, kojima nikad kraja, pa je tako odgovor izostao. Dužna sam ti i fotografije, koje nažalost i opet ne šaljem, ali to ne mojom krivnjom, nego zbog fotografa, koji in još uvijek nije kopirao. Inače su uspjele.

Na Paulin poticaj obratila sam se jednom vrsnom zagrebačkom botaničaru, koji radi na Botaničkom institutu, a bavi se prikupljanjem nazivlja biljki, te priprema objavljivanje te građe (ima oko 70.000 naziva). To je gospodin Šugar, inače rodom iz Istre i djak moga oca. Dakle, mogu Ti reći da nema nijednog naziv a izvan onih koji su objavljeni u Šulekovu djelu "Jugoslavenski imenik bilja", JA, 1879. Još sam mu ja dodala nazive iz Istre. Dakle, žao mi je da Ti ne mogu bolje udovoljiti. Vjerujem da si Šuleka konzultirao.

Toliko za sada na brzinu. Želim odvaliti taj dug, a ostajem još dužnik za fotografije. Osim toga, moram doći u Ljubljanu da čujem što to lijepog s narcisama spremaš.

Srdačno Tebe i Vidu pozdravlja vaša stara ... potpis

\section{Pismo 7 (18. listopada 1977.) - Milko Matičetov}

Draga Desa! Tvoja ganljiva skrb za moje narkisno vprašanje me kajpada sili da se Ti zahvalim takoj, še isti dan po prejemu pisma in prilog. Odlaganje na "jutri" utegne biti usodno in se zavleči v megleno, oddaljeno prihodnjost...

Od prilog (ne bom vpraševal, koliko stanejo, ampak se bom o priložnosti oddolžil in natura!), mi je najbolj pri srcu J. Murr (Die Pflanzenwelt etc.), ki sem večkrat naleteval nanj, ko sem se hotel informirati pri virih o antičnih mitih in imenih v zvezi z "mojo" rožico. Zadovoljil sem se s sestavki o N. v splošnih priročnikih (Roscher, Pauly-Wissowa in razne enciklopedije), vendar mi bo prav prišel tudi ta in oni drobec iz Tvojih prilog, ko 
bom pristopil k dokončni formulaciji besedila. Hvala!

Pauli G. sem se res priporočil, ko je pokazala zanimanje za moj "problemček" in bila priča, kako sem vlekel iz kolegov informacije iz raznih krajev (do Črne Gore!). Seveda me najbolj zanimajo imena ne iz cele Hrvatske, ampak le iz mejnih krajev ob robu Slovenije, od Međimurja mimo Obsotelja (Kumrovec) in vse do Istre. Šuleka sem seveda pogledal med prvimi deli, pripravljalnimi deli, ker ima tudi nekaj slovenskih imen. Iz njega so zajemali potem Tuma, Barle, Simonović, kot bi si podajali žogo, največkrat brez navedbe kraja, brez naglasov ipd. Da imajo rožice tudi svoje "korenike", da so zasidrane v neki kraj ipd. je pri nas upošteval najbolj dosledno goriški prof. Fran Erjavec. In on je potoval križem kražem po naših tleh, pred sto leti, pa je zašel tudi "v Čiče". Od tam je prinesel (izjemoma brez natančnejše oznake kraja) tudi ime sólnčica (sic!), ki mi ni in ni dalo miru. Njegov areal sem vsaj približno zajel šele pred tremi dnevi - na sobotnem pohodu v Čičarijo 15. t. m. Z Vido sva jo mahnila čez Golac na Vodice in naprej. V čudovitem sončnem vremenu sva doživljala Istro kot pesem. V Vodicah me je radovednost kajpada gnala k Studencu (kat' eksohèn) in k mogočni lipi, da bom imel lokacijo pred očmi ob pisanju, v katerem bom skušal podati jedro Tvojih informacij. Veselilo me je, da sem videl rojstni kraj prof. Josipa Slámarovega ${ }^{8}$ (upam, da sem prav ujel domače ime, izrečeno mimogrede, ne da bi si ga zapisal). Tudi sem slišal za Tvoj avgustovski obisk, ko sem se pri cerkvi informiral za pot do Studenca. Vendar sem vsega skupaj Vodicam posvetil lahko največ pol urice. Saj je bilo že skoraj ena ura popoldne in sonce je že kazalo željo, da se prevesi, pa sem moral hiteti, da še kaj ujamem. Pot me je potem peljala čez Dane in Trstenik proti Lanišću in Lupoglavu, od tam pa v smeri proti Buzetu in Kubedu nazaj proti Črnemu kalu in Ljubljani. Dan je bil kar naporen, ampak mi je prinesel vse, kar sem iskal, vse za pomirjenje moje vesti, da zdaj lahko odložim nadaljnje iskanje po Istri in ga prepustim hrvaškim kolegom.

Da moj ekskurz v vaša "Iovišča" ni bil odveč, da je bil nujen za reševanje tudi slovenskih imen, naj pokaže kratek pregled tega, kar sem ugotovil. Svojih izsledkov nikakor ne skrivam, saj jih bom porabil v članku, pa jih lahko tudi posreduješ gospodu Šugarju, ki ga bo kot Istrana morda veselil prispevek slovenskega terenca. Prve podatke sem dobil ob ekskurzu proti Buzetu v družbi z zgovornim Mikom Rožinim, glagoljašem s Krka. Evo jih: Črnica = padaníke; Požane = padaníke; Perce = bedeníke; Rumeni = benedíke. Na trgu s sadjem v Piranu sem dobil iz vasi Škofi in Krasići (Oprtalj) ime mandalénice. In zdaj, na pohodu, ki bi mu po Cezarjevo mogel reči "pressis itineribus", še tole: Dane $=$ medeníce, Brest $=$ mandaléne, Trstenik - Rašpor - Račja vas - Lanišće - Podgaće - Brgudac - Semići - Lupoglav = súnčica, Ročko polje in Buljavci pri Roču (ali Roću?) = šònčice, Čiritež = sònčice. Kakor kažejo ti podatki, je za Šulekov ostalo še

\footnotetext{
${ }^{8}$ Slamarovi su jedna grana Ribarićevih u Vodicama kojoj je pripadao i otac Jelke Radauš Ribarić.
} 
toliko neraziskanega, da bi tudi danes bilo vredno - čeprav po sto letih, zavihati rokave in iti na teren! Apropos Istra: med predavatelji na našem kongresu je bil prof. Rudan iz Pule (imena mu ne vem, ker tudi v seznamu udeležencev ni navedeno), doma seveda iz vasi Rudáni pri Žminju. Tam pravijo narcisam júrjevice, v bližnji vasi Póhmani pa ljúrjevice. Ostaja zame odprto vprašanje, kam lokalizirati Šulekovo ime bokalići, ki ga Šulek dolguje ali M. Sili ali J. Volčiču (takrat v službi v Zarečju). V Volčičevi biografiji vidim, da je 1855-71 službeno v Zarečju pri Pazinu. S tem bi bili lokalizirani bokalići. Ali je Milićević direktor v Pazinu ali v Poreču? Jaz imam na Slovenskem (Hrastovlje - Dol - Bezovica) obliko bokalètce; "bokaliće" moram pustiti za zdaj "viseti" v zraku in samo navesti, da eksistirajo. Na dosedanjih istrskih poteh ga nisem našel in do najdbe "bokalètc" sem ga celo odklanjal, pod vtisom Pleteršnika, kjer so bokalići sinonim za Lilium bulbiferum. Od naših botanikov na univerzi slišim, da zbira rastlinska imena na Hrvaškem tudi Radovan Domac. Ko si mi že toliko pomagala, ali bi hotela biti tako ljubezniva in zavrteti telefon in povprašati še njega, kaj ima sub voce Narcissus radiiflorus, stellaris, angustifolius pa še poeticus s terena, ne po Šuleku in Simonoviću (1959). Morda bi imel celo "bokaliće" lokalizirane? Kaj se ve. Če bi bilo to res, potem bi jaz popolnoma mirno spal - do nadaljnjega seveda!

Kakor vidiš, dobro konkuriram Miku Bonifačiću in sem kakor navita lajna. Oprosti mi. Hvala Ti za vse, za naprej in za nazaj. Mojim prisrčnim pozdravom se pridružuje tudi Vida! Milko

P.S. Še nečesa sem se domislil, da Te naprosim. Če bi že govorila z R. Domcom, skušaj zvedeti, ali imajo za rastline na Hrv. pregled rastišč, se pravi ob vsaki rastlini ali cvetlici navedeno ali morda celo že kar na karto vrisano mesto, kjer raste. Meni je taka karta, ki sem jo dobil od Toneta Wraberja na lj. fakulteti, zelo pomagala in mi olajšala delo, saj sem koj vedel, kje spraševati po narcisah in mi ni bilo treba davati $v$ temi in na slepo spraševati za ime rastline, kjer je sploh ni. Tako bi si tudi ne upal naprej hoditi po Istri brez poznavanja omenjenih osnov. Geološko: narcisa ne raste v krajih s flišem (laporjem, "brdskim" kamnom ipd.), pač pa uspeva v krajih z vapnencem (ali "belim k."). Od Mure do Beneške Slovenije imam danes ta dan ok. 65 imen za eno samo rožico narciso. To obdelujem kot primer, kaj se da zbezati. Naprej se seveda ne mislim vbadati s tem, naj delajo lingvisti in botaniki ali kdor hoče! Da se ne bi razni Novaki norca delali iz mene... Prisrčno! Milko

\section{Pismo 8 (19. listopada 1977.) - Milko Matičetov}

Dodatek v inštitutu, $v$ sredo zjutraj: $\vee$ tem uradnem okolju sem se še nečesa domislil, kar prilagam, da ne bo treba pisati posebej. Ne vem, če sem Te $v$ zadnjem pismu "pocukal za rokav" - se pravi naprosil za prispevek za naše Traditiones. Kuretov 
zbornik bo šel kmalu v tiskarno, vendar mi je Gavazzijev zbornik (v seriji Ethnologia Slavica) dal idejo: da tisti prispevki, ki so prišli z zamudo, pridejo napovedani v rednem zborniku, veljajo pa kot bi bili v prvem, radnem, čeprav bojo objavljeni v prihodnjem, za leto 1977, se pravi letošnje leto. Napoved bomo vtaknili zadnji hip nekam na konec zbornika, tik pred izidom. Torej imaš še nekaj časa, vsaj tja do konca januarja, da napišeš in nam dopošlješ svoj prispevek. Da bo Zagreb le zastopan še s kom in ne samo z neutrudnim Gavazzijem. Tudi s kom mlajšim in iz damskih vrst! Velja? Če sem Ti v tem smislu že pisal, ne zameri: repetita juvant. Rajši sedi k mizi in napiši, kar si nameravala že pred letom dni! In bodi zdrava! Milko

\section{Pismo 9 (24. listopada 1977.) - Jelka Radauš Ribarić}

Dragi Milko, dao si mi krasan primjer, kako se brzo obavlja korespondencija - i kako se na tom polju može izbjeći dugovanje popraćeno s morom i nelagodnošću grižnje savjesti. Bravo, jako si me razveselio - nisam mogla ni vjerovati da je to već odgovor na moje pismo - mislila sam da su se naša pisma križala. Uostalom, to dopisivanje u vezi s narcisama poprimilo je već pozamašan opseg - gotovo da bih mogla otvoriti poseban fascikl. Ništa zato, to mi je samo drago, jer sam tako u vezi s radom mojih kolega i baš me veseli ako kome u tom radu mogu malo i pomoći.

Zadivljena sam koliko si pronašao nazivlja za tako mali cvijetak. Upravo sam odložila slušalicu u uzaludnom pokušaju da stupim u telefonsku vezu s prof. Domcem za kojeg si me zamolio da ga nazovem i dobijem dodatne podatke o tvom cvijetu. Naravno, do gospode profesora ne može se tako lako doći - pa niti telefonom. Razgovarala sam s nekom gospođom dr. Pavletić, kojoj sam rekla o čemu se radi (nakon toga što mi je "ljubazno" objasnila da do prof. Domca ne mogu doći, ali da se i ona time bavi i neka njoj kažem što želim). Kad sam joj iz Tvog pisma iscitirala ono nekoliko latinskih imena za tvoje vrstice narcisa i zamolila je za lokalna narodna imena, ona mi je glatko i jako autoritativno objasnila da "narod nema tako bujnu fantaziju (sic!) da bi za svaku pojedinu vrsticu bilja imao posebni naziv i to još svoj lokalni (na rasponu od Međimurja do Istre)". Nije me htjela ni slušati za one brojne varijante koje si Ti sam pronašao, a koje navodiš u pismu. To je dakle stanovište visokokvalificiranog naučnog radnika s Botaničkog zavoda Prirodnoslovno-matematičkog fakulteta Sveučilišta u Zagrebu. Pitala sam i za "kartu rastlinstva" za Hrvatsku - naravno da je nema. Uostalom, ona me je otpravila s uputom da se pismeno obratiš ti sam prof. Radovanu Domcu pa da će ti on odgovoriti. Ne znam čemu tolike procedure - jedino ako baba nije ljubomorna da bi se neki ženski glas mogao dovući do uha "njenog" profesora. Oprosti mi na ovoj zlobnoj primjedbi, ali još sam ljuta zbog one njene primjedbe na račun maštovitosti naroda. Da nema te maštovitosti ne bi nas nikoga ni bilo, bili bismo majmuni. Svi su veliki znanstvenici samo na maštovitosti 
gradili svoje velike zamisli, a svi oni svoje korijenje imaju u "narodu". Uostalom, upravo se sada ja sama "probijam" kroz zapletene labirinte narodne maštovitosti na polju narodne umjetnosti u drvu - i itekako čvrsto osjećam svu njezinu veličinu i ljepotu. Dakle Milko, žao mi je, morat ćeš Domcu sam pisati.

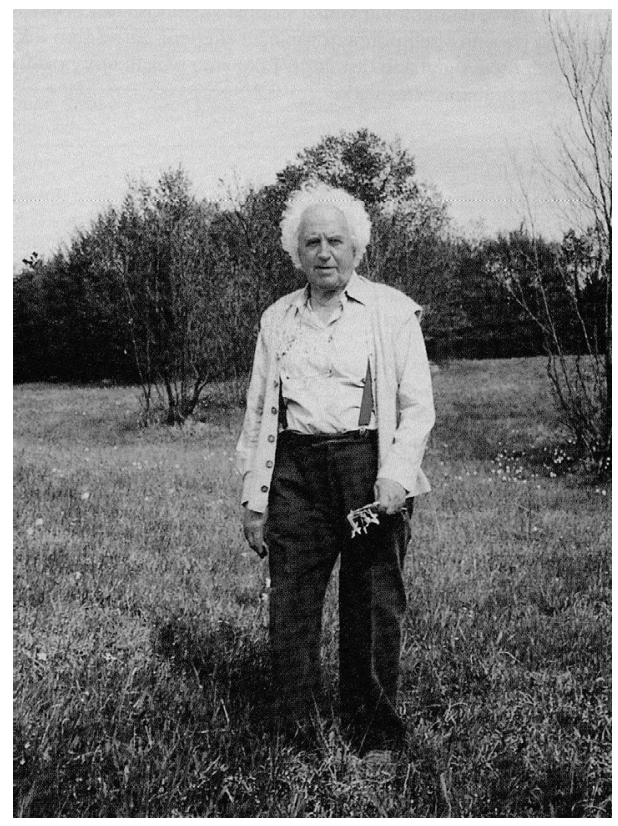

Slika 1: Akademik Milko Matičetov s tri narcise u ruci (Izvor: Traditiones, vol. 28/l, 1999:268)

Kad već govorim o tome što radim, odmah ti odgovaram i na tvoj poziv za suradnju u Kuretovu zborniku odnosno "Traditiones". Sasvim mi je jasno da bih u tom zborniku morala sudjelovati. Upregnut ću sve snage da obećani prilog napišem, a to je još onaj davno obećani prilog: "Predenje bez preslice u sjeverozapadnoj Hrvatskoj". Nadam se da vas neću prevariti tj. da ću uspjeti napisati, odnosno dovršiti i izbrusiti ono već nekad ranije napisano. Volila bih to i zbog starog prijateljstva prema Niki Kuretu, a i zato da se jedanput pojavim u "Traditiones". Primila sam i tvoj članak o svetcu sa medvjedom, među kojima je i moj istarski sv. Nikifor. Zanimljivo i zgodno - progrizla sam se s mukom kroz makedonski, naravno, ne od riječi do riječi. Bome, lakše mi je bilo s onim ranije poslanim na talijanskom. Vidim da si jako marljiv - ja nisam. Doduše, izišle su mi "popularne" knjige "Vezak vezla" i "Narodne nošnje Hrvatske" za potrebe turista, iako dosta opsežne. Nažalost se izdavači kod toga uvijek jako samovoljno ponašaju pa knjiga ne ispadne onako kako ju čovjek sam želi vidjeti. No ipak, tu smo. Šaljem Ti i ja mali prilog koji sam još 1974. napisala, a tek je ovih dana izašlo. Šaljem Ti i još jedan 
kseroksirani tekst koji je slučajno zaostao kod mene, a za tvoje narcise.

Jako mi je drago da si posjetio selo mojih pradjedova, Vodice u Ćićariji. Moga se oca svi dobro sjećaju jer je bio prvi školovani Vodičanin, a osim toga jako angažiran na dizanju naroda, kako u ekonomskom pogledu (zadruge), tako i u nacionalnom i kulturnom (škole, društva itd.). Bio je najbliži suradnik Laginjin i najmlađi istarski narodni zastupnik odabran u Sabor koji se zbog Prvog svjetskog rata nije više sastajao. A onda, onda se moralo u emigraciju - tako da je najzrelije i najmuževnije svoje doba proveo kao biljka istrgnuta s korijenom iz rodne grude. Mislim da mu je taj neposredni kontakt sa zavičajem, njegovim ljudima, njihovim govorom, običajima i problemima, pašnjaci i nebo čarobne Ćićarije uvijek nedostajao. Ah, o tome bi se moglo i moralo puno napisati. Znam da bih bila to dužna napraviti (...)

Eto, opet jedno veliko pismo da Ti ukrade dragocjeno vrijeme. Oprosti! Srdačno Tebe i Vidu pozdravlja vaša ... potpis

\section{MILKO MATIČETOV O TEMI NARCISA}

Milko Matičetov, dvije godine nakon ovog dopisivanja, objavio je svoj već u Uvodu naveden sjajan poduži rad o bedenicama/narcisama (Matičetov 1979).

U potpoglavlju naslovljenom "Pregled in pretres imen" / "Pregled i potraga za imenima" na osnovi začuđujuće velikog broja skupljenih imena za narcise (u Sloveniji i u hrvatskom dijelu Istre) donosi dvije karte njihove raširenosti. Nakon toga autor ta imena raščlanjuje na 13 tematskih skupina prema značenju pojma u nazivu (str. 282): ${ }^{9}$ I. Slatki Ijepljivi sok (npr. medenica/bedenica), II. Srkanje soka (npr. sugalica), III. Lukovica kao sastavni dio cvijeta (npr. česnikovca), IV. Vrijeme cvatnje (npr. jurjevka), V. Osobna imena bez povezanosti s vremenom cvatnje (npr. ivanica), VI. Krajolik (npr. roža s Slavnika), VII. Usporedba iz žive prirode (kukavica), VIII. Usporedba iz predmetnog svijeta (npr. bokalić), IX. Astralna usporedba (npr. sončica), X. Usporedba iz religijskog kruga (npr. Marijina palčka), XI. Nejasna povezanost (npr. jálovka), XII. Deformacija učenoga imena (npr. bernacis), XIII. Prijenos imena s drugog cvijeća (npr. lilija). Na kraju članka (str. 292-299) Matičetov donosi svoje komentare uz svaku od tih cjelina.

Tu ćemo u skupini I. naći njegovo razmatranje o nazivu bedenica koji vezuje uz sok sladak kao med - bedenica/medenica. U odjeljku II (str. 292) naći ćemo naziv sügovica iz Vodica na Ćićariji koji je Matičetov dobio od Radauš Ribarić, a koja ga je pronašla u

\footnotetext{
${ }^{9}$ Osim tematske podjele nazivlja za taj cvijet Matičetov donosi i popis imena abecednim redom (Matičetov 1979:283-289), dodajući u bilješci tumačenje kratica rječnika i ostalih vrsta izvora iz kojih je crpio te podatke.
} 
očevu doktoratu (Ribarić 1940:195). Tamo stoji da biljka sadrži slatki sok koji djeca sišu, sügaju. Matičetov navodi da je Ribarić uz ćićku riječ sügati (onda i uz naziv sügovica za narcisu) predložio, a Petar Skok (1973:357) ujedno i potvrdio, njezinu rumunjsku etimologiju (Matičetov 1979:288, 292). Zanimljiva je u skupini VII Matičetova asocijacija uz naziv za narcise štrkovo cvetje koje nalazi uz Muru. Usporedbu između cvijeta narcise i rode/štrka nalazi u cvijetu i ptici koji oboje stoje na dugoj "nozi" sa sličnim zadebljanjem u njezinu pregibu i s pognutom glavom/cvijetom. Ništa manje zanimljivo nije njegovo razmatranje o imenu nadjevenom tom proljetnom cvijetu u skupini VIII koja se odnosi na imena iz predmetnog svijeta. Tu ćemo tako naći naziv ključavnica koji autor povezuje uz kljuku i ključ na osnovi zakrivljenosti stapke narcise pri njezinu vrhu. Naći ćemo i nazive krancljevke te venci koje on povezuje opet s antičkim "erinijskim vijencem", ali i sa zlatnim vjenčićem pronađenim u grčkom grobu u južnoj Italiji. Značajan je i naziv sónčica iz skupine IX koji je, kako navodi, otkrio Fran Erjavec kod Ćića. "Sunčani" naziv, kako kaže "sončno" ime, uputio je Matičetova na njegov mogući pjesnički i obredni značaj. Od istarskoga pazinskog etnografa, kolege Josipa Milićevića, saznao je za slične nazive za narcise u Istri od Berma do Žminja - sunčica, sunčanica, a doznao je za "sunčano" ime i u Sloveniji kod Karavanki - sônčznca. U skupini X Matičetov iz, kako kaže, religiozne sfere navodi nazivlje za narcisu Marijine palčke i Jožefove palčke uz svoju asocijaciju na poznatu legendu o štapu/palici koji se u ruci sv. Josipa zazelenio i rascvao.

Ne samo na osnovi ovog članka, nego i na temelju uvida u korespondenciju Matičetova i Radauš Ribarić vidljivo je da je autor uložio mnogo vremena i osobito lingvističkoga ekspertnog znanja u istraživanje značenja toga fitonima. Uz velik trud u prikupljanju građe o imenima za narcise (čak 65!), pa i uz navođenje vrijednih asocijacija uz njih, velika je šteta što autor nije napisao i objavio najavljeni drugi dio članka sa svojim razmišljanjima o mitološko-obrednom aspektu ove teme te također najavljeni zaključak (usp. kraj cjeline I - Uvod). Pa ni u Matičetovu arhivskom materijalu - u mapi označenoj nazivom "Bedenice" arhiviranoj u Inštitutu za slovensko narodopisje u Ljubljani gdje je nekada radio - nije mi bilo moguće naći nikakve zapise koji bi se odnosili na taj važan aspekt istraživanja. ${ }^{10}$ Cilj mi je naime (bio) pronaći, pa onda i usporediti, autorova i moja razmišljanja uz mitološko-obredni aspekt koji bi se mogao povezati uz ovu temu.

\footnotetext{
10 Posebno želim zahvaliti na srdačnosti i pomoći Ingrid Slavec Gradišnik, predstojnici Instituta, prilikom moga posjeta Institutu 7. veljače 2018. godine, te dokumentaristici gđi. Stanki Drnovšek na pripremi arhivskog materijala.
} 


\section{NOVA INTERPRETACIJA TEME}

U korespondenciji Matičetova i Radauš Ribarić uočljiva je velika zainteresiranost i polet kojim razmatraju odabranu tematiku. ${ }^{11}$ Odaju to, vidjeli smo, brojne izjave iz devet pisama (usp. cjelinu II. Korespondencija). No, posebno oduševljenje pobuđuju kod Matičetova podaci koje je dobio od svoje hrvatske kolegice nakon njezina terenskog obilaska Vodica, rodnog sela njezina oca, zbog čega je, kako je napisao u pismu 4, morao razmisliti o izmjeni naslova svoga članka.

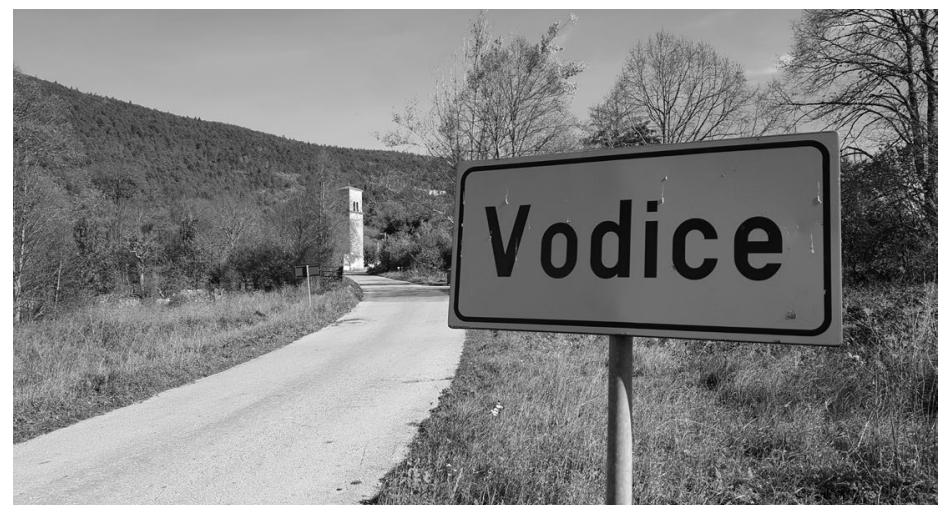

Slika 2: Ulaz u Vodice, Ćićarija

(Foto: J. Vince Pallua, listopad 2018.)

Na tom tragu posvetit ćemo se temi običajnih proljetnih praksi s izvorom/vrelom, narcisama i lipom u Vodicama u Istri te na početku kratko rezimirati o kakvim je to njezinim terenskim podacima iz sela Vodice na Ćićariji riječ. J. Radauš Ribarić u prvom je pismu iznijela svome slovenskom kolegi vlastita sjećanja na pripovijedanje njezina oca12 o obroncima oko sela Vodice ${ }^{13}$ bijelih od narcisa/sugovica koje je narod bacao u vrelo žive vode iznad sela, nerijetko ga zagađujući. Nakon povratka s jednodnevnog terena u Vodicama u kolovozu 1977. godine Radauš Ribarić (pismo 3) šalje Matičetovu podatke

\footnotetext{
${ }^{11}$ Vidljivo je da Matičetov svoj miran san uvjetuje rješavanjem nekoga znanstvenog problema. Autor naime u pismima na dva mjesta svoj oduševljen i prisan odnos prema narcisama, tj. prema problematici koju istražuje, označuje kao "moji cvetki" (pismo 5) i "moja rožica" (pismo 7). Naime, pridjev "moj" ne pokazuje osobno prisvajanje objekta istraživanja ili kakvu isključivost, nego osobni prisan odnos istraživača prema odabranoj temi.

${ }^{12}$ Riječ je o jezikoslovcu Josipu Ribariću (Vodice, 1880. - Zagreb, 1954.), ocu J. Radauš Ribarić, a momu djedu. U svom članku Milko Matičetov (1979:278, bilj. ${ }^{*}$ ) piše podrobnije o Ribariću, a opširna biografija iz pera njegove kćeri J. Radauš Ribarić objavljena je 1991. godine u Buzetskom zborniku br. 16 (Radauš Ribarić 1991).

${ }^{13}$ Vodice, selo na planinskom lancu Ćićarija, općina Lanišće, smješteno je blizu slovenske granice
} 
koji su je, kako kaže, oduševili, a koje je on (pismo 4) ocijenio predivnima (čudovitima) i dragocjenima (dragoceno pismo). Evo ukratko tih njezinih sabranih podataka s terena: Riječ je o izvoru žive vode koji ni za najvećih vrućina nije presušivao. Služio je za pojenje blaga i ispiranje robe. No, vrelo je dvadesetih godina 20. stoljeća zazidano, a ostavljeno je korito za blago.

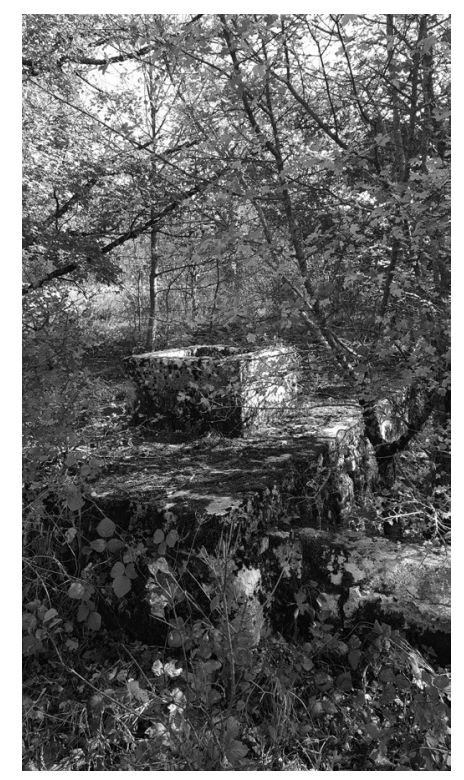

Slika 3: Zazidano vrelo Studenac

(Foto: J. Vince Pallua, listopad 2018.)

na raskrižju cesta Buzet-Obrov i Jelovice-Mune kao važna prometna točka toga dijela Ćićarije. Tek u ranom srednjem vijeku može se govoriti o seoskom naselju koje se u pisanim vrelima javlja nakon 10. stoljeća kao dio tršćanske općine. Nakon toga Vodice potpadaju akvilejskom patrijarhu, knezovima Goričkim, a krajem 14. stoljeća dolaze pod vlast Venecije kao dio Rašporske gospoštije (selo se spominje u Rašporskom urbaru 1285. godine). Vodice su stradale od osmanskih upada potkraj 15. stoljeća, a 1523. prelaze u vlast Habsburgovaca. Od tada je dio granice austrijskog i mletačkog područja išao između Vodica i Dana (usp. Istarska enciklopedija 2005:882; Jakovljević 2001:266-269).

Tijekom 16. i 17. stoljeća stanovnici Vodica doselili su se u to opustjelo selo iz dalmatinskoga zaleđa: "U jugozap. Istri i u Vodicama novi je istarski ikavski štakavsko-čakavski postmigracijski dijalekt složene strukture u kojoj gl. jezični sloj čine značajke ikavske čakavštine iz zadarskoga zaleđa, ali su održane i značajke asimiliranih ikavskih štakavskih štokavaca podrijetlom iz makarskoga (podbiokovskoga) kraja, koji su u Istru stigli u migracijskome valu s čakavcima ikavcima, a u većem ili manjem broju i jezične značajke starosjedilačkih čakavaca ekavaca" (Istarska enciklopedija 2005:154). S tim znanstvenim spoznajama u suglasju je i usmena predaja: "Što se pak tiče podrijetla mnogobrojnih obitelji Ribariča (32) u Vodicama, spomenimo da su prema pučkoj predaji njihovi predci onamo došli iz Dalmacije. Kada i kuda, ne znaju ni najstariji ljudi, a svi se slažu da su prije Ribarića u selu sigurno bili Rupene" (Ribarić 2002:81). 
Svi su se stariji ljudi tada još sjećali da su bacali sugovice i kamenčiće u Studenac jer je u njihovoj mladosti vrelo još bilo otvoreno. Uz to se vrelo, kako izvješćuje Radauš Ribarić, odvijao poseban običaj svakog proljeća: u proljetno doba djeca bi ubrala tri cvijeta (po jednoj kazivačici i sedam) i bacala ih u vrelo, a uz njih i tri kamenčića. Narcise, nikakvo drugo cvijeće, bacala bi u Studenac "kao dar da se ne bi utopila" i to samo jednom u godini kad bi u doba njihove cvatnje prvi put prošla kraj toga vrela. Osim darivanja izvora narcisama posvjedočili su joj da su sugovice nosili na dar do križa pričvršćenoga na staru veliku lipu na Mlaki, ${ }^{14}$ tj. da su narcise, kako su joj posvjedočili, "bogiču vrgli na dar". Na kraju pisma Radauš Ribarić samo ukratko iznosi svoje asocijacije - da joj se čini da je riječ upravo o senzacionalnom običaju još do nedavno sačuvanoga vegetacijskog kulta (vrelo, lipa, prvo proljetno cvijeće). Donosi i mišljenje da bi bacanje kamenčića u vrelo mogla biti simpatička magija (neka se utopi kamen umjesto mene). Ističe jednokratno darivanje cvijeća za napredak u cijeloj godini, a brojeve tri (i sedam) uočava kao magijske brojeve. Svi ti elementi izazvali su u Matičetovu reakciju oduševljenja zbog terenskih otkrića iz sela Vodice u Istri koja je dobio od svoje hrvatske kolegice. U njima nalazi poveznicu između antičkih svjedočanstava i današnjih suvremenih narodnih tradicija koju smatra, kako kaže, nevjerojatno arhaičnom, neočekivanom i jedinstvenom.

Milko Matičetov dakle, kako je već istaknuto, dobivene podatke iz Vodica izrijekom povezuje uz antičku, osobito grčku baštinu. ${ }^{15}$ Ipak, možemo se zapitati ne bi li se "Matičetove narcise" i ovaj kult ne samo vegetacije nego i vode iz sela Vodice u Istri izvor, narcise, lipa - pobliže mogli odrediti nekim drugim obredno-mitološkim kulturnim naslijeđem. Pokušat ću u ovom poglavlju ponuditi promišljanja o ovdje izloženoj problematici u takvom drukčijem obredno-mitološkom interpretativnom smjeru.

Činjenica je da je u proljeće, u svim vremenima i kulturama, pravilno odvijanje vegetacijskog ciklusa i njegovo obnavljanje jamčilo život i opstanak čovjeka i svih živih bića na zemlji. Proljeće je nagovještaj nadolazeće sezone buđenja i obnove prirode.

\footnotetext{
${ }^{14}$ Mlaka je mikrotoponim, ujedno i mikrohidronim u selu Vodice koji spominje i Josip Jurišević u novinama Istra (Jurišević 1939a:4). Taj mikrotoponim dio je sela Vodice, ojkonima s također "vodenim predznakom" sadržanom u njegovu nazivu. Oba naziva pokazuju važnost plodonosne vlage i vode potrebne vegetaciji u agrarnoj godini o čemu će kasnije biti riječi.

${ }^{15}$ Vidljivo je to i na temelju navođenja grčkog imena za narcisu, Nárkyssos, ali i na osnovi navođenja imena triju njemačkih znanstvenika koje spominje u pismu 4: Paulyja, Wissowa i Roschera. Naime, Realencyclopädie der classischen Altertumswissenschaft kapitalno je enciklopedijsko djelo u nizu od osamdesetak svezaka i godišta, započeto u Stuttgartu 1839. godine, koje su uredila dvojica autora: August Friedrich Pauly i Georg Wissowa. Djelo je posvećeno razdoblju antike, a najčešće se navodi u skraćenom obliku prezimenima autora kao Pauly-Wissowa, kako to čini i Matičetov. Spominjući i Wilhelma Heinricha Roschera koji se osobito bavio grčkom i rimskom mitologijom, Matičetov je očito ciljao na njegovo najpoznatije djelo Ausführliches Lexikon der griechischen und römischen Mythologie, sv. 1-7, Leipzig, 1902.-1909. Konačno, cvijet narcisa dobio je ime prema Narcisu, lijepom mladiću iz grčke mitologije koji se zaljubio u vlastiti odraz u jezeru.
} 
Narcise rastu početkom proljeća, spadaju u prvo proljetno cvijeće pa su, uz visibabe, jaglace i šafrane, postale simbolom nagovještaja ponovnog rođenja i vječnog obnavljanja prirode (Germ 2002:84).

Nalazimo kod Matičetova znakovit naziv za narcise - jurjevke, koji je povezan uz proljeće i uz Jurjevo, blagdan sv. Jurja, u hrvatskoj pučkoj tradiciji često shvaćen kao prvi dan proljeća, odnosno kao početak gospodarske godine. Naime, kao i mnogi drugi kršćanski sveci koji su nadomjestili pretkršćanske bogove sv. Juraj je supstitut Jarovita/ Jaryla/Jarila, boga proljetne vegetacije i plodnosti, praslavenskoga božanskog junaka vegetacije koji svakog proljeća dolazi iz daleka kraja i otvara godinu, a starim je Slavenima nova godina padala na posljednji mladi mjesec pred proljetnu ravnodnevnicu. ${ }^{16}$ "Uoči Jurjeva djevojke se umivaju na zdencu (...) beru mirisno cvijeće i, najviše u godini na taj dan, gataju njime, te pletu vijence koje bacaju u vodu vodenim vilama rusalkama u čast" (Bajuk 1999:156). I slovenski etnolog Niko Kuret u prvoj knjizi (Pomlad / Proljeće) svoga četveroknjižja Praznično leto Slovencev (1965.-1970.) drži da je Jurjevo po seoskom kalendaru početak proljeća i da je kod Slavena sv. Juraj nadomjestio neko važno pogansko proljetno božanstvo, možda Jarila (Jarnika), Vesnika čija je zasluga bila da se priroda svake godine opet ozelenila, da je stoka mogla ponovno na pašu i da su usjevi i mlado zelenje s mladim suncem opet oživjeli (Kuret 1965:267). Četvrt stoljeća prije Kureta Milovan Gavazzi opširno piše o Jurjevu u svojoj knjižici Godina dana hrvatskih narodnih običaja (1939., 1988.). U novije pak vrijeme o Jarilu/Jurju kao o Perunovu sinu, u praslavenskom mitu kao o glavnom obnovitelju vegetacije, studiozno su pisali Radoslav Katičić i Vitomir Belaj. ${ }^{17}$

\footnotetext{
16 "Mladomu bogu, koji je poslije pokrštenja Slavena identificiran sa svetim Jurjem, izvorno je ime najvjerojatnije bilo Jarovit i u hipokorističkim likovima Jarylo ili Jarila [Katičić 2010:437]. (...) Tu se polazi tragom daljnjih slavenskih usmenih tekstovnih predaja koje se odnose na dolazak mladoga boga Jarila iz daleka na svoju svadbu u očevu dvoru, a potječu od ulomaka slavenskog pretkršćanskog sakralnog pjesništva" (Katičić 2010:439).

${ }^{17}$ Tu se u prvom redu misli na petoknjižje što ga je akademik Radoslav Katičić tiskao između 2008. i 2017. godine: Božanski boj - tragovima svetih pjesama naše pretkršćanske starine (2008.), Zeleni lug - tragovima svetih pjesama naše pretkršćanske starine (2010.), Gazdarica na vratima - tragovima svetih pjesama naše pretkršćanske starine (2011.), Vilinska Vrata - tragovima svetih pjesama naše pretkršćanske starine (2014.), Naša stara vjera - tragovima svetih pjesama naše pretkršćanske starine (2017.). No, valja naglasiti da su pojedinačni Katičićevi članci o ovim temama počeli sustavno izlaziti već od 1987. godine u bečkom časopisu Wiener Slavistisches Jahrbuch, a onda i u časopisima Filologija (2003., 2005., 2008.) i Studia ethnologica (1989., 1990., 1991.). Prof. dr. Vitomir Belaj, emeritus Filozofskog fakulteta Sveučilišta u Zagrebu, u svojim se knjigama također pozabavio likom mladog boga Jaryla i sv. Jurja kao njegove interpretatio christiana: Hod kroz godinu. Mitska pozadina hrvatskih narodnih običaja i vjerovanja (1998., 2007. - 2. dopunjeno izd.) i Sveti trokuti - Topografija hrvatske mitologije - u suautorstvu s Jurjem Belajem (2014.), te najviše u člancima objavljenima u časopisu Studia ethnologica (1989., 1990., 1993.).
} 
Sve je ovo navedeno kako bi se uputilo na proljetne običajne prakse, osobito u okviru jurjevskih događanja koja pokazuju početak proljeća i kojima se otvara nov godišnji vegetacijski ciklus i nova agrarna godina, osnažuje priroda i zaštićuju ljudi od bolesti i svakog zla. Poznato je da su takve običajne prakse nekada imale mnogo veće značenje kao obredni čini popraćeni izgovaranjem svetih tekstova koji su onda, nerijetko tek u fragmentima, stigli do nas u obliku narodnih pjesama. ${ }^{18}$

A što je u tom kontekstu s narcisama, studencem i lipom u Vodicama na Ćićariji? Kako interpretirati dragocjena svjedočenja s terena koja je Matičetov dobio od svoje hrvatske kolegice? Zašto su trima narcisama darivali vrelo/studenac i u njega bacali i tri kamenčića? Zašto su to činili samo u proljeće prvi put kad bi prošli kraj toga vrela? Zašto su narcisama darivali i drveni križ pričvršćen na obližnju veliku prastaru lipu? Sve su to pitanja na koja valja pronaći odgovor.

Uz vodu ili uz upotrebu vode u mnogim su se kulturama izvodili brojni rituali nerijetko sačuvani u obliku običaja ili pak u dječjem folkloru.

U IV. odjeljku ciljano ćemo se baviti proljetnom običajnom praksom uz vodu, posvjedočenom u Vodicama, selu koje i svojim imenom odaje usku povezanost s vodom. ${ }^{19}$ Taj vodički "vodeni" element valja dodatno povezati uz Matičetovu temu istraživanja - bedenice/narcise. ${ }^{20}$

Poznato je da je do kraja 19. stoljeća glavna gospodarska grana u Vodicama bila stočarstvo, osobito ovčarstvo, te da je Jurjevo kao blagdan bio ne samo pravi početak proljeća nego i pastirski blagdan:

"Na Jurjevo 23. travnja, 'pravoga početka proljeća' i 'pastirskoga blagdana', u svim je hrvatskim krajevima više uobičajenih rituala s vodom pa se i u terminološkom smislu s pravom može govoriti o jurjevskoj vodi. ... Ona je, kao i nešto kasnija ivanjska voda, bilo obavezno kupanje ljudi i stoke. U reduciranom obliku može se vršiti tek umivanje ljudi, posebno mladeži, vodom u kojoj je potopljeno mlado bilje - analogno umivanju na Cvjetnicu" (Grbić 2012:63). ${ }^{21}$

\footnotetext{
${ }^{18} \mathrm{Uz}$ obrede, poznato je, izgovarali su se sveti tekstovi. U Vodicama 1977. godine (pismo 3, J. Radauš Ribarić) dobiven je odgovor: "kraj Studenca se ništa nije govorilo niti izgovaralo".

${ }^{19}$ Ojkonim Vodice odražava postojanje, pa i postojanost nepresušne vode $u$ tom selu, vidjeli smo čak žive vode. Jednaka ili pak slična toponimija može se naći po svim slavenskim jezičnokulturnim prostorima. Vrelo o kojem je riječ zove se Rašošica, češće zvano Studenac i nalazi se u neposrednoj blizini sela. Voda se spušta s brežuljka koji lokalno nazivaju Glavičorka s vrhom zvanim Žabnik (podaci dobiveni u Vodicama 2018. godine).

${ }^{20}$ Ponovimo, bedenice je slovenski naziv za narcise, naveden i u naslovu Matičetova članka, dok je fitonim sugovice lokalno ime za taj cvijet koji dolazi od istrorumunjskog sugu, supt 'sisati' ... sisati slatki sok iz stabljike narcise (usp. Ribarić 2002:215).

${ }^{21}$ Usp. i Gavazzi 1988:57 itd.
} 
U vodičkom slučaju ne raspolažemo podacima o bilo kakvim tradicijskim radnjama s krupnom ili sitnom stokom uz vodu, no to ujedno ne znači da takvih običaja nije bilo, osobito ako imamo na umu pastirski element u selu Vodice koje se sve do 19. stoljeća kao na glavnu granu privrede i opstanka oslanjalo upravo na ovčarstvo s ekstenzivnom proizvodnjom sira. ${ }^{22} \mathrm{No}$, gore spomenuto potapanje mladog bilja na Jurjevo, osnaživanje vode mladim biljem, što je vrlo česta praksa, u vodičkom slučaju proljetnoga mladog cvijeća narcisa (nikakvoga drugog cvijeća), posvjedočeno je terenskim zapisom Radauš Ribarić u kolovozu 1977. godine. Četiri desetljeća kasnije, u listopadu 2018., darivanje Studenca trima sugovicama ponovno mi je posvjedočilo dvoje kazivača - 63-godišnji gospodin Josip Ribarić i gospođa Slava, 90-godišnja kazivačica, tijekom moga terena u Istru. ${ }^{23} \mathrm{Na}$ pitanje zašto su djeca darivala sugovicama vrelo Studenac dobila sam odgovor da se to radilo za zdravlje. Zasigurno su i žitelji Vodica početkom proljeća željeli osigurati dobar i plodan tijek agrarne godine - nove gospodarske godine, zaštititi zdravlje ljudi i stoke i zatražiti zaštitu od svakog zla. Sjetimo se da je više kazivača 1977. godine ustvrdilo da se darivanje vrela trima sugovicama odvijalo samo jednom u godini i to kad se u vrijeme cvatnje prvi put prolazilo kraj vrela, dakle krajem travnja, a Jurjevo je 23. travnja. Gavazzi ističe da se jurjevske tradicije mogu nazivati proljetnima jer je "sam datum Jurjeva manje važan i zacijelo je tek s vremenom postao glavni nosilac brojnih proljetnih običaja koji su se okupili oko ovoga datuma kršćanskog kalendara" (Gavazzi 1988:53).

Bismo li na osnovi izloženoga mogli smatrati da je upravo dječji folklor $u$ reduciranom obliku uspio sačuvati nekadašnji obredno-običajni čin darivanja vode sugovicama/jurjevkama upravo na Jurjevo krajem travnja kada cvatu narcise - na dan početka prvih radova izvan kuće, dan pravog početka proljeća i na pastirski blagdan koji je stočarima Vodica zasigurno bio osobito važan? Pokušat ćemo odgovoriti na to pitanje.

Darivanje vode odvijalo se samo jednom godišnje, prvi put kad se prolazilo kraj Studenca u okviru dječjeg folklora (djeca od 12 do 13 godina) u kojem se nekadašnji

\footnotetext{
22 Prije doseljenja stanovništva u Vodice tijekom 16. i 17. stoljeća (usp. bilj. 13) spominju se stoka i Jurjevo u okviru podatka da je selo imalo 17 selišta koja su na blagdan sv. Jurja plaćala po pet maraka i po jednu ovcu i jedno janje po svakom selištu: "Villa de VODICA habet mansos XVII qui solvunt prò prego in festo sancti Georgij omni anno Marchas quinque denariorum. / Jtem solvunt in dicto festo sancti Georgij pecudem vnam et vnum agnum prò quolibet manso sed gastaldio ville est exemptus. / Jtem solvunt directam decimam omnium suorum agnorum de qua decima presbiter ville habet quartesium et decimam vnius vicini / retinent in se propter aliquas suas consuetudines (...)" (Klen 1960:19; Jakovljević 2001:266).

${ }^{23}$ Gospodina Josipa Ribarića (63), imenjaka prof. Josipa Ribarića, oca J. Radauš Ribarić, spominjem punim imenom i prezimenom nakon što me moj kazivač za to ovlastio. Ujedno mu zahvaljujem što me vodio po Vodicama, vozio po obližnjim selima Ćićarije i što je došao autom po mene u selo Mune do kojeg dopire autobusna linija iz Rijeke. Gospođa Silvana Luković, zvana Slava, rođena je u Vodicama, a udana u Spinčićima kraj Kastva.
} 
obredni čin jednokratnoga jurjevskog/proljetnog darivanja (žive) vode mladim proljetnim cvijećem sveo ne nužno na jurjevsko (na dan Jurjeva), nego na darivanje vrela onoga dana kad se u proljeće prvi put prođe kraj njega. Konačno, poznat je pripjev u pjesmi koji upravo naglašava spomenutu jednokratnost pri darivanju samoga mitskog junaka: "Juraj nije svaki dan/ već u ljetu jedan dan/ Darujte ga, darujte ga/ Juru zelenoga". Jer, Jurjevo se hodanje, trudan hod kojim donosi pokretanje vegetacije, vraća svake godine upravo na određeni dan.

Proljetno darivanje vode u Vodicama postavit ćemo u okvir praslavenskoga osnovnog mita o svetoj svadbi Jarila, mladog boga vegetacije, i njegove sestre Mare koja predstavlja mladi aspekt božice povezanog uz plodnost. ${ }^{24}$ Voda je, nema sumnje, igrala vitalnu ulogu u duhovnosti Slavena - imali su kult vode i zdenaca, častili "žive vode"25 - rijeke, potoke, izvore i zdence. ${ }^{26} \mathrm{U}$ Vodicama je dakle u razdoblju od četiri desetljeća posvjedočeno bacanje triju narcisa i triju kamenčića u Studenac, elemenata iz prirode znakovitog broja tri, kad se početkom proljeća prvi put prođe kraj zdenca. ${ }^{27}$

Uz vodički primjer vode i mladoga proljetnog cvijeća možemo se prisjetiti već spomenutoga jurjevskog umivanja ljudi, posebno mladeži, vodom u kojoj je potopljeno mlado bilje. Reducirani je to oblik često prvoga godišnjeg kupanja ljudi i stoke u jurjevskoj vodi kojom se želi zaštititi od bolesti i svakog zla. ${ }^{28}$ Je li proljetno darivanje vodičkog Studenca trima narcisama ono već spomenuto osnaživanje vode na početku agrarne godine pri pokretanju godišnjega vegetacijskog ciklusa? Radauš Ribarić i

\footnotetext{
${ }^{24}$ Kao pojašnjenje manje upućenima u slavensku mitologiju donosim vrlo kratku informaciju: "Komparacijom i analizom slavenskih i baltičkih obrednih pjesama i motiva, ustrajnim dugogodišnjim filološkim radom, hrvatski znanstvenik Radoslav Katičić je na temelju prethodnih istraživanja Rusâ Ivanova i Toporova uspio detektirati i rekonstruirati vrijedan dio naše duboke prošlosti. U tome mu se pridružio i veliki hrvatski etnolog Vitomir Belaj. Njima dugujemo to što su nam otvorili prozor u svijet koji je do tada bio nepoznat i skriven, a danas je još uvijek živ u našem jeziku i običajima. Najvrjedniji dio tih istraživanja upravo je onaj koji se tiče svete mitske svadbe praslavenskih božanstava plodnosti Jarila i Morane, brata i sestre, o kojoj se do sada znalo tek ponešto" (Kipre 2014:34).

${ }^{25}$ U puku se tekuća voda, tzv. živa voda, smatra plodonosnom i ljekovitom jer zbog svoje pokretljivosti donosi svježinu i odnosi štetno i opasno (Dolenčić, prema Novak 2007:187).

${ }^{26}$ Najraniji spomen te činjenice donio je kroničar Prokopije iz Cezareje koji piše da su Slaveni "također obožavali rijeke, nimfe i neka druga božanska bića" (Procopius W, 14, paragraf 24, citirano prema Kajkowski i Kuczkowski 2017:16).

${ }^{27} \mathrm{O}$ simboličko-mitološkoj bremenitosti broja tri doista nije za ovu priliku potrebno trošiti riječi. Osnovne informacije dostupne su u poznatom rječniku Dictionnaire des symbols: Mythes, rêves, coutumes, gestes, formes, figures, couleurs, nombres francuskog uredničkog dvojca Jeana Chevaliera i Alaina Gheerbranta, prvi put objavljenog u Francuskoj 1969. godine. Dostupan je u hrvatskom prijevodu kao Rječnik simbola - mitovi, sni, običaji, geste, oblici, likovi, bolje, brojevi, Nakladni zavod Matice hrvatske, Zagreb, 1989.

28 "Bolesnici s kožnim bolestima ulazili bi trokratno u vodu, izražavajući želju za ozdravljenjem u obliku jednostavne molitve" (Moszyński 1967:507, citirano prema Kajkowski i Kuczkowski 2017:17).
} 
Matičetov interpretiraju to darivanje u sklopu vegetacijskog kulta osnaživanjem vode magičnom snagom prvoga proljetnog cvijeća - (simpatičkom) magijom²9 - kako bi se zadobilo zdravlje (tri narcise) i kako se ne bi utopilo (tri kamenčića). Spomenimo da i Gavazzi ustanovljuje da se za najveći dio jurjevskih običaja može reći da su magijskoapotropejskog značenja (Gavazzi 1988:42). Branko Fučić, služeći se obilno građom iz prvog izdanja iste knjižice (1939.), zelenilo na Jurjevdan promatra u svjetlu pretkršćanskih magijskih vjerovanja u povezanosti tih starih s novima u magijskoj zaštiti od demonskih sila te kao stimulativni postupak za rodnost i plodnost stoke, živadi i agrarnih kultura (Fučić 1962:134-135). ${ }^{30}$

Spomenuli smo već da su djeca u Studenac, uz tri narcise, bacala i tri kamenčića "da se ne bi utopila" (terenski podaci iz pisma 3 Jelke Radauš Ribarić, 1977. godine). U listopadu 2018. godine potvrđen mi je taj podatak. Tada sam od mog kazivača Josipa Ribarića doznala i nešto iz njegove obiteljske povijesti, a što se tiče opasnosti od utapanja koju je predstavljalo tada još uvijek otvoreno vrelo. Naime, Milka i Roža, dvije sestre njegova djeda, kao djeca su učiteljici "išla nabrati ruže" te, nakon što je krenula "da će smočit' rožice", ${ }^{31}$ jedna od njih se utopila nakon čega su pokrili Studenac. ${ }^{32}$ । moja već spomenuta kazivačica Slava spominje taj zdenac, zazidani Studenac u koji se bacalo po tri sugovice i tri kamenčića. Rečeno je već da Radauš Ribarić drži da bi "bacanje kamenčića u vrelo mogla biti simpatička magija - neka se utopi kamen umjesto mene" (1977., pismo 3). No, može se pomisliti da je takvo tumačenje odraz seoske memorije, sjećanja upravo na spomenuti nemili događaj utapanja djevojčice iz Vodica.

Ipak, darivanje Studenca u Vodicama moglo bi se protumačiti na drukčiji način. Pritom zasigurno nije potrebno krenuti od vode kao primarnog izvora života i na tom tragu percipirati tri kamenčića kao ostatak drevne zamjenske obredne realizacije darivanja vode ljudskom žrtvom. Naime, poznato je da su se ljudske žrtve prinosile rijekama u drevnim civilizacijama. ${ }^{33}$

\footnotetext{
${ }^{29}$ Pojam simpatička magija uveo je škotski antropolog James George Frazer u djelu Zlatna grana podrijetlo religijskih obreda i običaja (1890.). Riječ je o magiji kojom se uz pomoć simbola oponaša željeni predmet ili osoba u nastojanju da se ispuni nekakva želja.

${ }^{30}$ U Zelenom Jurju kao personifikaciji, obrednoj realizaciji demona vegetacije, pretkršćanski supstrat vide J. G. Frazer i W. Mannhardt, a D. Zelenin promatra ga kao kakvoga biljnog/drvnog demona. $\mathrm{Na}$ osnovi ukrajinskog materijala A. Afanasjev vidi ga pak u Jarilu, staroruskom božanstvu rodnost i proljeća. Na slovensko-hrvatskoj građi isti mitski lik smješta Marolt u praslavenski kontekst videći ga kao Jarila (usp. Fučić 1962:135 - bilj. 31, prema Gavazzi 1939:50 i Huzjak 1957:40-41).

${ }^{31}$ Ruže/rožice - lokalni izraz za cvijeće općenito. Uočljivo je da moj kazivač, provevši radni vijek u Kopru u Slovenij, a i zbog blizine Vodica slovenskoj granici, pomalo miješa hrvatski i slovenski jezik ${ }^{32}$ Studenac je zazidan dvadesetih godina 20. stoljeća.

33 "Svake godine bacali su Rimljani u Tibar po dvadeset i sedam lutaka - to je bila zamena ljudske žrtve reci Tibru; takve žrtve dobijao je i Nil, u vremenu kad počne da raste - i to: najpre je dobijao živog čoveka, a docnije lutku" (Čajkanović 1973:235).
} 
"I naš narod, u svojoj dalekoj prošlosti, prinosio je ljudske žrtve rekama (...) Reka, i vode uopšte, i same traže ljudske žrtve. U Dunavu se svake godine mora udaviti po jedan čovek; ako Neretva ne bi preko godine podavila sedam ljudi, ona bi potekla krvava - veruje naš narod u tome kraju. (...) Nije nemoguće da je u sasvim dalekoj prošlosti naš narod prinosio u prolećnoj sezoni, stvarne ljudske žrtve reci; docnije bi te žrtve bile samo nagoveštene: čovek bi bio bačen u vodu, ali ne bi bio udavljen; dodola bi bila bačena u reku, ali bi joj se dopustilo da posle opet iz nje iziđe" (Čajkanović 1973:235-236).

Netko bi u tom kontekstu (a spominje se upravo proljetna žrtva!) mogao pomisliti da bi se obdarivanje vrela vodičkim kamenčićima moglo jednako interpretirati. Naime, upravo u jurjevskom kontekstu spominje se djevojačka žrtva:

"Ima i kod nas jedan običaj o Đurđevdanu da se ide na reku i tu, 'šale radi', poneka devojka gurne u vodu i, razume se, odmah zatim izvuče na obalu. To što se danas smatra za šalu bila je nekada, po svoj prilici, ozbiljna kultna radnja. Ja držim da ovde imamo ništa manje nego zamenu, supstituciju ljudske žrtve" (Čajkanović 1973:12). ${ }^{34}$

U rekonstrukciji autor dalje prikazuje rijeku kao božanstvo kojemu se žrtvuje djevojka i daje kao nevjesta što je, kako kaže, poznat slučaj tzv. svete svadbe u poganstvu. No, Čajkanović ne upućuje na praslavenski osnovni mit o svetoj svadbi Jarila/Jurja i božice Mare, njegove sestre, kojom se pokreće proljetni ciklus, nego zaključuje, poput drugih znanstvenika svoje generacije, da "po sili analogne magije" spomenuta ljudska žrtva omogućuje plodnost polja (usp. Čajkanović 1973:12).

Osim te dramatične ljudske žrtve vodi znano je darivanje vode darovnim žrtvama u piću, raznolikoj hrani - medu, kruhu itd., ili pak prinošenje žrtve bacanjem tkanina i vune u vrelo.

"Slika sv. Petke, najčešće drvena skulptura, stavljala se obično na zdence.

Sve do 20. stoljeća očuvao se u istočnih Slavena običaj kulta vodā i zdenaca povezan s tom sveticom. Ona se tu jasno pokazuje kao uosobljenje mitskoga bića i nema razloga sumnjati u to da ona nastavlja predodžbu o božici Mokoši preodjevenu tek površno kršćanski. Prinosile su joj se žrtve tako što su se bacale u zdenac različite tkanine, lanena kudelja, ispredene niti i ovčja vuna. Taj se običaj zove mokrida" (Katičić 2011:214).

${ }^{34}$ Usp. i Grbić (2012:53, bilj. 40) u kojoj se spominje ljudska žrtva u čast duha izvora, vrela rijeke Bune nedaleko od Blagaja u južnoj Hercegovini. 
Ipak, vodu se u proljeće najčešće daruje cvijećem - ono što smo vidjeli u vodičkom primjeru. Zanimljivo je pak da smo uza nj vidjeli i interpretaciju o (simpatičkoj) magiji koju donosi Radauš Ribarić ("neka se utopi kamen umjesto mene"), ali i novu mogućnost tumačenja kao seoske memorije konkretnog slučaja nemilog događaja utapanja djevojčice u Vodicama, podatak koji sam dobila na terenu u listopadu 2018. godine.

Postavimo pitanje: Nije li gore navedena interpretacija o magičnoj moći ${ }^{35}$ mladih proljetnica sugovica koje valja baciti u Studenac, tek iskrivljena predodžba davnoga pretkršćanskog obreda uz vodu, reducirani i ispražnjeni oblik nečega mnogo značajnijega za našu interpretaciju? Značenjsko-hijerarhijski kronološki slijed mogao bi se postaviti ovako: nekadašnji (sveti) obred postao je tradicijski ponavljani proljetno-jurjevski običaj koji se sveopćim zaboravom izvornog značenja sačuvao tek u degradiranom obliku dječjeg folklora. U praslavenskom mitu o plodnosti i rodnosti dolaskom božanskog junaka, boga vegetacije Jarila/Jurja iz daleka, konačno se nakon duge zime otvaraju vode kao ključan element pokretanja (agrarne) godine (Katičić 1987; Belaj 1998). U praslavenskom osnovnom mitu o svetoj svadbi Jarilo/Juraj je dakle mladi bog vegetacije, godišnje rodnosti koji donosi vodu i u spoju s božicom Marom, ${ }^{36}$ svojom sestrom, djevojkom povezanom sa Suncem, pokreće vode, godišnji ciklus i omogućuje buđenje prirode.

Znanstvena interpretacija pomoću magične moći zelenila jednoga drugog proljetnog mitskog primjera i neprikladnost takvog tumačenja jasno je istaknuta u odlomku koji, zbog njegove jasnoće i eksplicitnosti, pa i didaktičnosti, donosimo u cijelosti:

"Juraj je pošao na put preko mora, kroz šumu u ravno polje. Njegov je dolazak osigurao rodnost njivama. Kako je to bilo postignuto? Bilo bi naivno povjerovati u tumačenja starijih istraživača o magiji zelenja koju su zamišljali neuki ljudi izvodeći običaje kao što je ovaj sa zelenim Jurjem. Takvo se vjerovanje moglo pojaviti tek nakon što se raspala stara religija u kojoj se znalo kako je uređen svijet, tek nakon što su zaboravljeni mitski događaji s početka Povijesti. Zeleni lik nije donosio plodnost zato što bi zelena grančica analognom magijom sadržavala u sebi magičnu moć koju Ijudi onda kontaktnom magijom prenose na ljude, stoku i usjeve. Taj je lik samo ponazorio ono što pokreće zbivanja u svijetu, a to su život i djela mitskih junaka, u konkretnom slučaju boga vegetacije.

Zeleni je Juraj u obrednom prikazu bog vegetacije koji donosi plodnost. Tu nije bilo nikakve magije. Ona se javlja tek kada se stara religija

\footnotetext{
${ }^{35}$ Usp. gore i Gavazzi te Fučić koji jurjevske običaje tumače također magijsko-apotropejskim elementima.

${ }^{36}$ Usp. dalje u raspravi nazivlje za narcise - Mari(ji)ne palčke, Maričice te Sončice/Sunčice/ Sonnenblumen.
} 
'ispraznila' i postala 'praznovjerjem', ali ne u odnosu na kršćansku vjeru nego na pogansku. Tek nakon što su se pokidale veze između obrednog čina i svetih tekstova činovi su postali običajima, sveti tekstovi narodnim pjesmama a obredni su učinak učenjaci počeli kojekako tumačiti učeno klasificiranim magijama" (Belaj 2007:225-226).

U vodičkom slučaju obredni se čin nije sačuvao više ni kao običaj nego, i on ispražnjen od značenja, tek u dječjem folkloru, što se i inače često zbiva.

Zeleni je Juraj personifikacija praslavenskog, ujedno i pretkršćanskog boga proljetne vegetacije i plodnosti Jarila. $U$ praslavenskom mitu o plodnosti i rodnosti, mitu o svetoj svadbi, vidjeli smo, on donosi vodu i u spoju s božicom Marom, svojom sestrom, omogućuje buđenje prirode. "Jurjev hod, upravo njegovo dolaženje, donosi rast vegetacije, što je razumljivo jer Juraj, u biti jest vegetacija. Vegetacija u čijoj je srži obnove voda, pa je Juraj, potpuno u skladu sa svojim i velesovskim značajkama, i vodonosac" (Šantek 2018:471). U tom kontekstu držimo da je odraz obrednosti i mitološke bremenitosti moguće pronaći u nazivu za narcise - jurjevke ${ }^{37}$ - koji valja povezati uz proljetni blagdan sv. Jurja, kršćanskog nasljednika mladoga (pra)slavenskog boga Jarila, njegova interpretatio christiana. Središnji jurjevski lik, zeleni Juraj, "oslobodit će svoju buduću suprugu nebesnicu Maru iz okova ili sanduka (tj. zimskog zatočeništva)" (Bajuk 1999:157).

A što je s Marom i nazivima za narcise koji bi se usko mogli povezati s tim važnim, također (pra)slavenskim mitskim likom?

Nazivlje za narcise Marijine palčke i Jožefove palčke M. Matičetov opravdano ocjenjuje "stopostotno dijelom religioznog područja", objašnjavajući ovaj drugi naziv poznatom legendom o procvalom štapu u Josipovoj ruci. Naziv Marijine palčke povezuje pak s "etiološkom zgodbicom" kojom će se, kako najavljuje, pozabaviti u drugom dijelu članka (Matičetov 1979:297). Jedan i drugi naziv, kako vidimo, postavlja autor u kršćanski religiozni kontekst.

Možemo pak postaviti pitanje nisu li nazivi Marijine palčke (Zabukovje pod Liscom u Sloveniji), ali i naziv Maričice (Perka, Zvoneća u Istri) ${ }^{38}$ koje donosi Matičetov upravo kristijanizirane izvedenice kojima bi prvotni naziv bio onaj u kojem se pojavljuje Jarilova/

\footnotetext{
${ }^{37}$ Premda je u Vodicama, istarskom selu na samoj granici sa Slovenijom, naziv za narcise sugovice (prema sisanju slatkog soka iz narcisa - usp. bilj. 20), a ne jurjevke, Matičetov donosi brojne takve nazive u susjednoj Sloveniji, ali i u Istri (te jedan podatak u Slivnu kod Imotskog). On se naime, kako je vidljivo i u naslovu njegova članka, usredotočio na područje Slovenije i Istre.

${ }^{38}$ Istarski zaselak Perka kraj Zvoneće na opatijskom krasu mogao bi nas, kao i neki drugi slični toponimi (primjerice Periščica - Novak 2007:189), podsjetiti na mitsku boginju, Perunovu ženu, ali i na cvijet peruniku koja odzvanja mitskim prizvukom o kojem je o tom cvijetu već mnogo toga znano i pisano. No i Zvoneće slično odzvanja.
} 
Jurjeva sestra Mara: Marijine $\rightarrow$ Mari(ji)ne $\rightarrow$ Marine palčke i Maričice. Tada bi se moglo zaključiti da se naziv toga proljetnog cvijeća nije odnosio na kršćansku djevicu Mariju, nego na mitski lik iz stare vjere - mladu proljetnu boginju Maru koju Jarilo/Juraj, njezin brat, dolazi osloboditi kao buduću suprugu iz zimskog zatočeništva. A Mara, folklorni lik mlade vesele boginje kojoj je namijenjena važna uloga mladenke u mitu o svetoj svadbi koja pokreće godišnju rodnost, u proljeće počinja incest sa svojim bratom Jarilom/ Jurjem da bi na kraju godine postala okrutna i opasna Mora, Morana. Drugim riječima, uz Matičetovu opravdanu ocjenu da "naziv Marijine palčke stopostotno ulazi u religioznu sferu" možemo određenije ustvrditi da taj naziv prvotno ulazi u sferu tzv. stare vjere, tj. da su Marijine palčke tek kristijanizirani oblik Marinih palica? Naziv Maričice svojim oblikom dodatan je prilog takvoj konstataciji.

U tom kontekstu valja poći korak dalje i uočiti jedan drugi naziv za narcisu koji je također usko povezan s Marom, ženskim mitskim likom, kao što su to Mari(ji)ne palčke, Maričice. Matičetov je naime u više lokaliteta pronašao za narcise naziv sončice, solnčice, sunčanice, sunčice (Matičetov 1979:296-297). To je ime zabilježio u Istri i u Sloveniji, a naziv sónčica zapisao je Fran Erjavec 1879. godine upravo kod Ćića na Ćićariji. Od Josipa Milićevića, istarskog etnografa, saznao je za slične nazive u Istri od Berma do Žminja sunčica, sunčanica, a i u Sloveniji kod Karavanki - sônčənca. Povezanost sa Suncem našao je i u njemačkom nazivu za narcisu Sonnenblume (ibid.:288, 297). Svakako, uz mlado raslinje ide i mlado sunce pa se neminovno nameće poveznica između sunca i narcisa u nazivu sončice. I hrvatski naziv sunovrat ulazi u taj "sunačni" fitonimski krug (Matičetov ga navodi kao solnovrat, "poslovenjeni” izraz - Matičetov 1979:291).

No, i naziv sončica/sunčica trebalo bi možda dodatno sagledati u drukčijem interpretativnom okviru. ${ }^{39}$ Naime, ne samo naziv za narcise Marijine palčke, Maričice, pa onda Mari(ji)ne palčke, Marine palčke, Maričice, nego i naziv sončica/sunčica označuje istu mitsku osobu. Jer, Sončica/Sunčica jest Mara. ${ }^{40}$

Valja istaknuti da osim u Vodicama takvo proljetno darivanje vrela nije potvrđeno ni u jednom od istarskih sela, pa ni u kojem susjednom. Iz toga možemo zaključiti da je ta praksa donesena iz starog kraja - dalmatinskog zaleđa ${ }^{41}$ koje je, kao što su i Vodice, također dio južnoslavenskog područja. ${ }^{42}$

\footnotetext{
${ }^{39} \mathrm{U}$ taj krug moglo bi ući još dosta naziva koje donosi Matičetov, primjerice - bokalići/bokaletce, ključavnice, čarovnice, majkice itd.

${ }^{40}$ Usp. npr. Belaj koji upućuje da se Gromovnikova kći Mara u slavenskim tekstovima dovodi u usku vezu sa Suncem, kao što se čini i u drugim predajama u kojima se, primjerice u Vedama, djevojka često naziva Sūryā, Sunčeva kći, Sunčeva djevojka što ju legitimira kao neprijepornu božansku osobu praindoeuropske starine (Belaj 2007:249-251, 438)

${ }^{41} \mathrm{O}$ doselidbi tijekom 16. i 17. stoljeća u Vodice usp. bilj. 13.

${ }^{42}$ Takav zaključak ponuđen je i u interpretaciji običaja prporuša u Vodicama, štokavsko-čakavskoj
} 


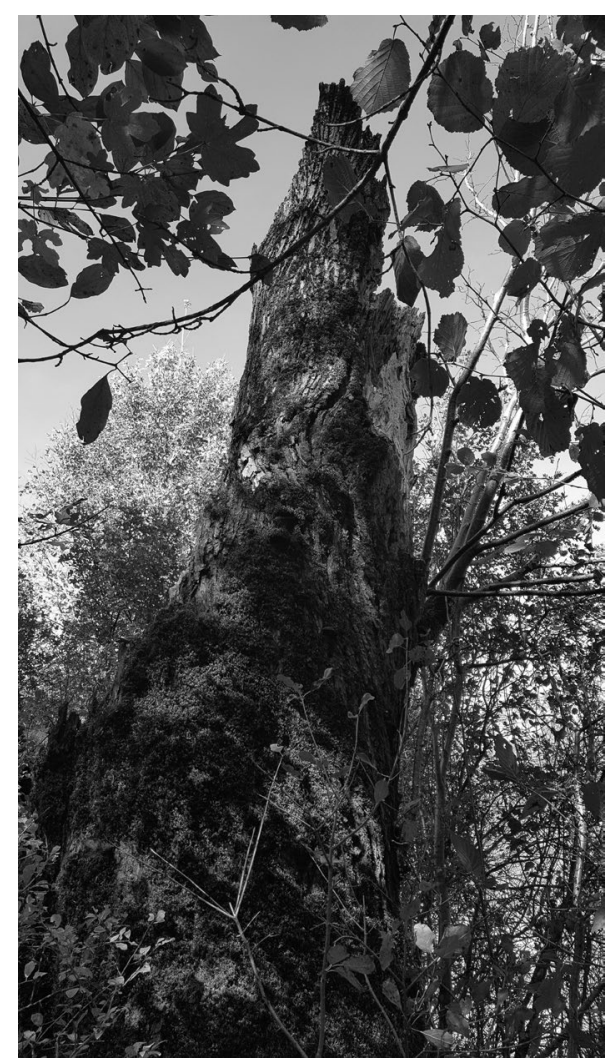

Slika 4: Stara lipa pogođena gromom prije dvadesetak godina (Foto: J. Vince Pallua, listopad 2018.)

Uputimo se dalje od S t u d e n c a do obližnje I i p e. Naime, osim darivanja vrela Studenca narcisama iz istog smo pisma Radauš Ribarić Matičetovu dobili svjedočanstvo o darivanju narcisama bogiča/boga. U pismu 3 stoji: "Sugovice su se nosile i do jednog križa na Mlaki, 'tamo smo isto sugovice bogiču43 vrgli. To je bia tako kako jedan dar'." No križ, kako doznajemo, nije bio samostojeći nego pričvršćen na obližnju lipu. Kad sam svoju devedesetogodišnju kazivačicu zapitala sjeća li se nečega na toj velikoj staroj lipi,

oazi kako Ribarić naziva svoje selo, u kojem je polovinom 20. stoljeća još uvijek bio živ: "Smatram taj običaj vrlo značajnim za podrijetlo stanovnika štokavsko-čakavske oaze. Mislim da ne bi bilo teško dokazati da on nije sjevernočakavski, nego će biti po svoj prilici donesen iz Dalmacije ili uopće s Balkana, a ni naziv valjda nije slavenski (ukoliko možda nije u vezi s riječju pr̈pa i pr̈por 'mješavina pepela i vode') nego romanski. Starosjedilački Južni Slaveni na poluotoku Istri ne poznaju pṛporüše" (Ribarić 2002:85). "Molitva za kišu - Prastari narodni običaj u Vodicama" primamljiv je naslov članka o prporušama kojim je potvrđeno da se taj ljetni običaj za zazivanje kiše izvodio "do pred prije drugog svjetskog rata" (usp. Jurišević 1939b:2).

${ }^{43} \mathrm{U}$ Vodicama ćemo primijetiti utjecaj slovenskog načina izgovaranja i pisanja glasa ć kao č. 
odgovor je bio jednak onomu od prije 40 godina: "Sjeća se da je na lipi bio drveni križ". ${ }^{4}$

Prisutan je dakle i kod lipe, u neposrednoj blizini Studenca, čin darivanja narcisama - "bia je to kako jedan dar". Već smo se gore susreli s jurjevskim stihom o darivanju: "... Juraj nije svaki dan/ Već u ljetu jedan dan/ Darujte ga, darujte ga/ Juru zelenoga". Kao ilustraciju brojnih primjera darivanja vode, ovaj put na Novu Godinu, spomenimo i stihove iz Bele krajine: "Ná, voda, to darujem tebi, tudi ti daruj meni!" ili pak iz Pomurja koje izgovaraju djevojke: "Ljuba voda, jaz te darujem od dna do dna, sem za moža že zadosti godna" itd. (Kuret 1970:241). Dvjema se rečenicama osvrnuo na pitanje važnosti obrednog darivanja i R. Katičić:

"Valja imati na umu da ako darivanje i nije sastavnica mitskoga zbivanja koje obredu daje njegov vjerski smisao, ono ipak može biti i vjerojatno jest arhaična sastavnica obredne radnje, pa i one pretkršćanske na praslavenskoj vremenskoj razini. Pri hodu po polju onoga koga su tek pokršteni Slaveni nazvali Jurjem u prvobitnoj mitskoj predodžbi vjerojatno doista nema nikakva darivanja, ali ga je isto tako vjerojatno bilo već kod pretkršćanskih ophodnika koji su obredno izvodili taj hod i time ga, kako su vjerovali, podupirali i osnaživali" (Katičić 2010:64-65).

U takvom je scenariju moguće vizualizirati Vodičane u nekadašnjem proljetnom/ jurjevskom ophodu. Nakon darivanja Studenca oni odlaze do obližnje, pedesetak koraka uz to vrelo smještene stare lipe na kojoj je pričvršćen drveni križ. U Katičićevoj knjizi Zeleni lug naći ćemo u istočnoslavenskoj, ruskoj jurjevskoj pjesmi da ophodnici, kao i Juraj, hodaju po polju, po oranicama te da njihov hod, kao i Jurjev, donosi polju rodnost. ${ }^{45}$ No, to nije sve. Vodičani su na lipu postavljali drveni križ, a iz pjesme doznajemo i to da ophodnici hodaju po polju i postavljaju križeve: "Rano smo ustajali, bijela lica umivali, okolo polja hodili, križeve postavljali, Jurja dozivali" (usp. Katičić 2010:61). ${ }^{46}$

Svakako da su u doba svoga doseljenja u Istru (usp. bilj. 13), a i mnogo prije toga, stanovnici Vodica bili kršćani. Ipak, moguće je pomisliti da se u Vodicama, premda tek u dječjem folkloru, zadržala pretkršćanska, ujedno praslavenska obredna praksa. ${ }^{47} \mathrm{Naime}$,

\footnotetext{
${ }^{44}$ Zasigurno nisam očekivala da ću na lipi blizu Studenca naći i danas pričvršćeni križ. No, nadala sam se da ću, kako je posvjedočeno prije četrdeset godina, vidjeti tu veliku staru lipu u neposrednoj blizini Studenca (usp. njezin položaj i veličinu u pismu J. Radauš Ribarić br. 3). Kako sam vidjela, a kako su me informirali, veliku tristogodišnju lipu pogodio je prije dvadesetak godina grom. No, i danas je moguće vidjeti njezino pozamašno deblo (usp. sl. 4). Bilo bi zanimljivo ustanoviti preciznu starost te lipe ${ }^{14} \mathrm{C}$ metodom ili pak dendrokronologijom.

${ }^{45}$ Spomenimo da se tik uz vodički Studenac i uz lipu nalaze nepregledna obradiva polja.

${ }^{46}$ Ivanov i Toporov (1974:181) pišu kako Rusi u jurjevskom ophodu nose i postavljaju križ na polju (usp. Katičić 2010:96, bilj. 75)

${ }^{47}$ Neki će se čitatelj zapitati bacaju li djeca možda i danas narcise u Studenac. Nakon što se
} 
često su pučka štovanja vode, pa i izvora i zdenaca, tek poganske prakse zaodjevene u kršćansko ruho. Poznato je da se Crkva protivila pretkršćanskim oblicima pobožnosti pa tako i kultu izvora, kultu drveća, lugova itd., o čemu nam svjedoče zapisi brojnih kršćanskih autora. Proces kristijanizacije bio je dugotrajan i ne svuda jednak. "Crkva se borila s 'kultom izvora' tijekom čitavoga srednjeg vijeka. (...) Svi pokušaji da se okonča s njihovom svetošću u poganskom poimanju propali su. Otuda potreba da se na drugi način 'kristijaniziraju' vode postavljanjem crkava, kapelica ili bar križeva u njihovu blizinu" (Kajkowski i Kuczkowski 2017:22).

Bismo li onda u takvom svjetlu mogli sagledati postavljeni križ na staroj lipi u neposrednoj blizini Studenca? Drugim riječima, pokazuje li križ na lipi odnos Vodičana, kao i Crkve, prema pretkršćanskim kultovima - kultu izvora (i kultu drveća?)? ${ }^{48}$ Nekadašnji jurjevski ophod, očuvan u Vodicama u obliku dječjeg folklora jednokratnim proljetnim darivanjem izvora i bogiča na lipi, mogao bi stoga čuvati tragove praslavenskog, ujedno i pretkršćanskog obreda koji su nakon kristijanizacije izvodili ophodnici da bi, hodajući poput Jurja po poljima, pokrenuli vegetaciju i plodnost. U bjeloruskoj proljetnoj ophodnoj pjesmi naći ćemo stihove:

"Po tvojoj njivi sam Bog hodi, sam Bog hodi, pet osoba vodi: prva je osoba - sveti Juraj, druga je osoba - sveti Mikola, treća je osoba - Sveta Trojica, četvrta osoba - sveti Petar, peta je osoba - sveti llija (...) Po polju, po njivi tu hodi sam Bog. Oni koji tu pjesmu pjevaju i oni koji ju slušaju razumiju to, dakako, kršćanski. Može dakle biti da se tu samo pribjegava najvišoj instanciji nadnaravnih sila. Ali može biti i to da je tu ostao trag toga da je onaj sveti Juraj koji hodi po polju bio bog poganskih Slavena. Dakako, bog koji je nosio drugo ime, a ne Jurbjb (23. travnja)" (Katičić 2010:22).

Katičić ujedno ističe da u hrvatskoj predaji u toj funkciji hodi samo Juraj, dok kod Bjelorusa to čine i ti drugi alopersonaži, kršćanske zamjene za božanski lik slavenskog poganstva - njegove interpretationes christianae (usp. Katičić 2010:17).

Hrvati iz Vodica sigurno su svoje darivanje "razumjeli kršćanski" (smatrali kršćanskim činom), kao i bjeloruski pjevači svoju ophodnu pjesmu. Tko je dakle bogič na lipi kojeg se daruje narcisama? Je li taj bogič Krist na (drvenom) križu ili je to u

dvadesetih godina izvor zazidao (usp. sl. 3), tako nešto više nije bilo primjereno, a osim toga činjenica je da je danas to selo znatno opustjelo i da u Vodicama od nekadašnjih 700 stanovnika živi samo, kako su me informirali, petnaest stari(ji)h ljudi pa je velika lijepa škola prenamijenjena.

${ }^{48}$ Kult drveća stavljen je u zagradu s upitnikom jer će se kasnije još raspravljati je li lipa (pra)slavensko drvo. "lako je kršćanska Crkva pokušala zatrti pogansko čašćenje drva, imalo je drvo važno mjesto još u kasnoj kršćanskoj simbolici i to u dva oblika: kao drvo života i kao drvo križa" (Šmitek 2011:85). 
pretkršćanskim vremenima bio bogić - mladi bog Jarilo ${ }^{49}$ Vidjeli smo naime u stihovima ruske jurjevske pjesme "Rano smo ustajali, bijela lica umivali, okolo polja hodili, križeve postavljali, Jurja dozivali" kako ophodnici, kao i Juraj koji je zamijenio Jarila, u jurjevskom (op)hodu kojim se želi potaknuti rodnost, nose i postavljaju križ na polju. Ponovimo da se lipa s križem, kao i vodički Studenac, nalaze tik do nepreglednih obradivih polja.

Vodičanima je bogič zasigurno bio Krist (ovdje na drvenom križu pričvršćenom na lipi) kojeg su darivali narcisama. Kazivači tu ne spominju darivanje trima narcisama, kao što to čine uz darivanje Studenca. Uz darivanje boga/bogiča na križu na lipi ne spominje se dakle broj narcisa. Broj, rekli bismo, ovdje nije važan.

Valja naime primijetiti da se utrojenost narcisa (i utrojenost kamenčića koji se bacaju u vrelo) spominje samo uz darivanje Studenca, ali ne i uz darivanje boga/bogiča na križu na lipi. Jer, on je j e d a n, on je - Bog. ${ }^{50}$

Crkva se, rekli smo, odlučno protivila poganskom čašćenju izvora i drveća pa je postavljala crkve, kapelice ili pak samo križeve kraj njih. U Vodicama je tako u neposrednoj blizini Studenca bio postavljen križ na stablo lipe. Blizu Studenca na raskršću glavnih cestovnih puteva nalazi se i crkva sv. Martina iz 1837. godine. Stara pak crkva istog titulara, izgrađena 1580. godine, stoji na groblju u gornjem, povišenom dijelu sela. I uz jednu i uz drugu crkvu nekoliko je golemih lipa koje mještanima daju potreban hlad za okupljanje, kao što je gotovo pravilo i drugdje u Istri i Sloveniji da uz kapelicu ili crkvu raste lipa. U već spomenutom Šulekovu članku naći ćemo zanimljiv podatak da u okolici Trsta "sve se zna po lipah, gdje su stare crkve; a gdje neima nikakve lipe, to možeš biti uvjeren, da je crkva iz naše dobe" (Šulek 1878:159). Zorno to pokazuje i primjer iz sela Slum, također na Ćićariji, u kojem ćemo naći neobično veliku lipu šupljeg debla najstariju i najveću u Istri. Tamo je romanička crkvica sv. Mateja iz 1870. sagrađena na mjestu starije iz 16. stoljeća, a podignuta uz tu veliku lipu (usp. "Slum" 2008; Istarska enciklopedija 2005:732). Godina 1555. uklesana je glagoljskim natpisom č.f.l.d. na konzoli kamenoga rebrastog svoda (Fučić 1982:327).

Ostavimo sada slumsku lipu i vratimo se "našoj", ipak nešto mlađoj lipi. Što je dakle s vodičkom lipom i križem na njoj, smještenom u blizini Studenca? Mogao bi netko, imajući na umu uvriježenu predodžbu o lipi kao (pra)slavenskom svetom drvu, pomisliti da je ovo darivanje bogiča povezano s njezinom praslavenskom i sveslavenskom svetošću. Moguće je naime pretpostaviti da se u pučkom štovanju lipe kriju kršćanski interpretirane poganske prakse. U tom kontekstu može se postaviti pitanje-zagonetku:

\footnotetext{
${ }^{49}$ Bogić je ovdje pretkršćanski mladi bog Jarilo, a bogič, pisan drukčijim dijakritikom, deminutiv od kršćanskog boga - Krista na križu. O različitom pisanju slova č i ć usp. još bilj. 43.

${ }^{50} \mathrm{Na}$ izravno pitanje momu domaćinu J. Ribariću što je bilo na lipi, odgovor je i sada glasio: "Bog je bio na toj lipi".
} 
Nije li možda pojam bogiča na lipi povezan uz svetost koju je prvotno mogla imati lipa?

A vrelo, lipa (potom i križ) motivi su koji se pojavljuju uz često citirani i komentirani primjer tzv. Kažotićevih lipa i zdenca kod sv. Linarta/Leonarda nad Cernikom u Slavoniji.

Zanimljivo je da je tek krajem 20. stoljeća Vitomiru Belaju, koji je pisao o blaženom Augustinu Kažotiću u pučkoj predaji (Belaj 1995), uspjelo detronizirati lipu s "dendropijedestala" s uvriježenom predodžbom o lipi kao (pra)slavenskom "svetom" drvu. Nakon više od jednog stoljeća rasprava upravo je na osnovi etnološkog materijala ${ }^{51}$ dokazano da lipa ima kultno značenje samo kod zapadnih Slavena, a kod istočnih (i istočnog dijela južnih) ona takvu ulogu nema ni u tragovima (usp. ibid.:409). Pisac izrijekom naglašava da

"pomnija analiza pučkih vjerovanja pokazuje da ni kod zapadnog dijela Slavena lipa nije sama po sebi sveto drvo, nego da je takvom postala tek nakon što ju je puk doveo u užu vezu s Marijom, Isusovom majkom (...) 'Štovanje' lipa bit će, dakle, stara vjerojatno pretkršćanska, srednjoeuropska pojava koja se proširila kod zapadnog dijela Slavena tek nakon prihvaćanja kršćanstva, i to u vezi s kultom Blažene Djevice Marije. Ovako oblikovana, ona pripada srednjoeuropskomu kršćanskom krugu" (Belaj 1995:409).

Spomenuti kult Djevice Marije, u odnosu na lipu, vidljivo je prisutan u pučkom vjerovanju Slovenaca: "U lipu ne udara grom 'jer se pod njom odmarala Bogorodica kad je bježala s Isusom'. Obratno, Srbi kažu da pod lipom ne treba spavati niti se od kiše zaklanjati 'jer u nju rado grom puca'" (Čajkanović 1985:166). Bez obzira na vjerovanje, vodičku je lipu, vjerovali ili ne, prije dvadesetak godina pogodio grom (usp. sl. 4).

Odgovor na gore postavljeno pitanje-zagonetku prilično je jasan. Lipa s križem, istina, našla se u vrhunaravnom kontekstu, ali ne onomu koji bi se mogao pripisati odjeku nekadašnje (pra)slavenske "svetosti" lipe. Osim toga, upravo ćemo kod Slovenaca (hrvatsko selo Vodice nalazi se na samoj granici Hrvatske i Slovenije) naići na izraz lipov bog u frazi "držiš se kakor lipov bog"52 (Šulek 1878:172). Takvu poveznicu između lipe i križa u toj frazi tumači Šulek podatnošću lipova drva za izradu kipova svetaca i osobito križeva pa zato otprije nazvanog lignum sanctum (ibid.:172).

Na moje pitanje zna li što se govorilo o vodičkoj lipi, moj mi je domaćin Josip Ribarić odgovorio: "Bog je bio na toj lipi”. A bogič ne visi samo na lipovu bogu - na križu, nego i na "našoj" lipi.

\footnotetext{
${ }^{51} \mathrm{U}$ članku je pokazano kako pisana predaja može potaknuti usmenu predaju te kako se predaje i kult, smještene u kulturnopovijesni okvir, mogu dodatno i dublje objasniti poredbenim etnološkim gradivom" (Belaj 1995:403).

52 Šulek ujedno navodi i tursku psovku "Krste lipovi!"
} 
U razmatranju svjedočanstava kazivača o vodičkom vrelu i lipi s križem iz 1977. i 2018., morali smo se utjecati brojnim nematerijalnim spoznajnim elementima. Naime, "veći dio ljudskoga ponašanja povezanog s vodom ne može biti očuvan u obliku arheološkog dokaznog materijala. To posebno vrijedi za pobožnost i ponašanje uz njega koje se većim dijelom događa bez ikakve materijalne pojavnosti" (Kajkowski i Kuczkowski 2017:27). To smo ponašanje pokušali postaviti u okvir prijelomnog doba godine s obnovom vegetacije s kojim su povezani ostaci pučkih jurjevskih/proljetnih ophoda, uz darivanje vrela, kao mogućim odbljeskom važnog dijela osnovnoga praslavenskog mita o godišnjoj plodnosti, rodnosti i svetoj svadbi mladog boga Jarila, vodonosca i pokretača vegetacije, i njegove sestre boginje Mare. Ujedno smo i nazivlje za narcise koje donosi Matičetov ${ }^{53}$ - jurjevke i Marijine palčke/Maričice - protumačili u kontekstu pretkršćanske stare vjere. Nasuprot tomu, pokazali smo da darivanje bogiča na lipi ne ulazi u taj krug i da to nije kršćanski interpretirana poganska praksa nekadašnjega pučkog štovanja lipe.

Jurjevo, uz Jurja koji je supstitut praslavenskoga mladog boga Jarila, vodonosca i poticatelja vegetacije, stoji na važnoj granici između zimske i ljetne polovine godine. U Vodicama nije izrijekom spomenuto Jurjevo, ali kazivači sustavno naglašavaju jednokratni obilazak vrela i križa na lipi te bacanje u vrelo isključivo narcisa. ${ }^{54}$ Po tome, nema sumnje, znamo da se ophod događa u doba cvatnje narcisa početkom proljeća, no u dječjem folkloru ne više na samo Jurjevo, ali ipak - jednokratno u proljeće. ${ }^{55}$ Dobivamo i drugu vremensku odrednicu - "kad se prvi put prođe kraj zdenca". Hod i čin darivanja vrela označuje točku u vremenu kao prekretnicu, prijelaz iz jednog u drugi dio (agrarne) godine. A starim je Slavenima, kako je već istaknuto, nova godina padala na posljednji mladi mjesec pred proljetnu ravnodnevnicu. Konačno, već smo uputili na stihove "Juraj nije svaki dan/ već u ljetu jedan dan/ Darujte ga, darujte ga/ Juru zelenoga". Jurjevo se hodanje, trudan hod kojim donosi pokretanje vegetacije, vraća svake godine upravo na određeni dan.

Još je jedna tradicija, također iz Vodica, očuvana opet u dječjem folkloru, posvjedočena u članku iz 1995. godine. Tamo smo se susreli s prijetnjom djeci Babom koju će, na putu iz Vodica prema Trstu, morati "v rit cekit", poljubiti u zadnjicu pri prvom susretu s njom (usp. Vince Pallua 1995/1996:285). ${ }^{56}$ Baba je u spomenutom kontekstu prostorna granica. ${ }^{57}$

\footnotetext{
${ }^{53}$ Kako smo vidjeli, Matičetov te nazive smješta, kako kaže, u kršćanski religiozni kontekst.

${ }^{54}$ Isključivanje svakoga drugog cvijeća isključuje ivanjsko, dakle ljetno darivanje vode cvijećem.

${ }^{55}$ Već smo spomenuli da Gavazzi ističe da se jurjevske tradicije mogu nazivati proljetnima jer je "sam datum Jurjeva manje važan i zacijelo je tek s vremenom postao glavni nosilac brojnih proljetnih običaja koji su se okupili oko ovoga datuma kršćanskog kalendara" (Gavazzi 1988:53).

${ }^{56} \mathrm{O}$ ovoj tek na prvi pogled lascivno sročenoj prijetnji saznala sam od svoje bake koja je u Zagrebu o tome zasigurno čula iz usta svoga supruga Josipa Ribarića.

${ }^{57}$ Ljubljenje Babe, sadržano i u samom naslovu članka (Vince Pallua 1995/1996), pronašla sam prije dvadesetak godina kod svih kamenih amorfnih Baba na Krku i u Istri smještenih, kako se
} 
Prijetnja djeci ljubljenjem ovog dijela tijela "Stare žene" sačuvala se i svela na dječji folklor u trenutku kada se ta tradicija prestala izvoditi jer su joj se značenje i smisao zaboravili (ibid.:285). Isti proces transformacije, vidjeli smo, dogodio se i s činima uz vodički Studenac. Katji Hrobat Virloget, uz pomoć studenta D. E. iz Venecije, pošlo je za rukom pronaći potvrde Babe u europskom folkloru izvan slavenskog područja - u Italiji i Francuskoj - i na osnovi toga utvrditi analogije Babe izvan slavenskog svijeta, ali i ovu istu prijetnju djeci, osobito u sjeveroističnoj Italiji58 (Hrobat Virloget 2013:154-155, 163 - bilj. 19, 2015:58). Štoviše, u dva sela sjeverne Italije "poljubiti Staru ženu ili poljubiti zadnjicu Stare žene značilo je otići nekamo prvi puta ili ući u nečiju kuću prvi put" (Hrobat Virloget 2013:154).

I tu, kao i u primjeru Studenca, susrećemo se dakle sa zajedničkim nazivnikom "prvi put" - bilo pri prvom prijelazu iz našeg područja na tuđi, novi teritorij kad se mora "poljubiti babu" (prostorni "prvi put"), bilo pri prvom prolasku s narcisama kraj Studenca u proljeće (vremenski "prvi put") koji označuje prijelaz iz zimskog dijela godine u drugi proljetno-plodonosni dio godine koji valja potaknuti darivanjem vrela narcisama. I jedan i drugi primjer posvjedočili smo upravo u Vodicama.

\section{Povratak Matičetovu i slovensko-hrvatskoj suradnji}

Pjesničko "sončno" ime / "sunčani" naziv za narcise, kako kaže Matičetov, uputio ga je na njegov mogući mitski i obredni značaj (Matičetov 1979:297). Na osnovi asocijacija koje se odnose na antičku, posebno grčku mitologiju, a koje Matičetov navodi kako u svojim pismima tako i u članku, moglo se i očekivati da je on današnje tradicije uz ovaj proljetni cvijet nastojao povezati upravo s antičkim tradicijama, posebno grčkim pjesničkim i obrednim praksama. Potvrđuje to i u spomenutoj mapi u Ljubljani nekoliko pronađenih naslova knjiga i leksikona o antičkoj mitologiji, a i literatura na koju

pokazalo, uvijek uz vodu da bih, kao krunsku potvrdu, istu obvezu ukazivanja poštovanja, pa i molbi prema toj značajnoj arhaičnoj ženskoj mitskoj figuri potvrdila i kod grobničke Babe isklesane u živoj stijeni, do 2018. godine jedine pronađene babe u ženskom obličju s naglašenim ženskim atributima (Vince Pallua 1995/1996, 2018). Grobnička Baba koju dakle također treba poljubiti i obdariti kad se prvi put kraj nje prođe, smještena je na ulazu u drevni grad Grobnik - na prijelazu iz jednog teritorija u drugi, a čiju granicu motri i njome upravlja sama grobnička Baba, "Gazdarica na vratima", kako je svoju knjigu 2011. godine naslovio Radoslav Katičić.

${ }^{58}$ U Liguriji naime "ako dijete padne, kaže se da je 'otišlo poljubiti stražnjicu Maimunne' ili pak 'otišlo poljubiti zadnjicu Stare žene (La Vecchia)'". Autorica zaključuje da "šmrkava Baba" ne može biti nego sama zemlja (Hrobat 2010:220, 2013:154). Mitska figura Babe povezuje se s određenim teritorijem (gradom, šumom, pašnjakom) u sklopu inicijacijskog obreda prvog ulaska na određeni teritorij (usp. Ravbar Morato 2007:58, prema Kropej 2013:192; Hrobat Virloget 2013:143, 160). Autorica svoju interpretaciju naziva "teritorijalnim rite de passage pri (prvom) prolasku ili ulasku u područje 'drugoga'” (Hrobat Virloget i Kavrečič 2015:81). 
se u članku i u pismima poziva (primjerice na poznati enciklopedijski priručnik PaulyWissowa). ${ }^{59}$ Također, u toj je mapi nađen i naslov poznatoga grčkog mita "Narcis i Eho" koji Matičetov spominje i u svom članku (Matičetov 1979:294). Osim toga, tomu u prilog nesumnjivo ide i njegova rečenica u pismu u kojoj izravno ističe da tradiciju u Vodicama na Ćićariji valja povezati s arhaičnim antičkim tradicijama: "Tvoj prispevek, se mi zdi, daje potrebno vezno gradivo med antičnimi pričevanji in današnjim sodobnim ljudskim izročilom, ki prav v Vodicah kaže neverjetno arhaično podobo, nepričakovano, enkratno" (pismo 4). Nazive pak Marijine palčke, Maričice, kako smo vidjeli, Matičetov smješta u kršćanski religiozni kontekst. Drugim riječima, kada su se Matičetov i Radauš Ribarić 1977. dopisivali i razmišljali o postavljenoj temi u pokušaju njezine obredno-mitološke interpretacije, nisu uzeli u obzir mogućnost utjecaja mitskih elemenata (pra)slavenske mitologije. Premda je bilo autora koji su i ranije pisali o praslavenskoj mitologiji, znatniji zamah u slovenskim i hrvatskim akademskim krugovima doživjelo je bavljenje mitologijom s takvim predznakom jedno desetljeće nakon njihova dopisivanja - osamdesetih godina 20. stoljeća koje na obje strane, uz znatne rezultate, traje i danas. ${ }^{60}$

Nakon ovoga konkretnog, s više strana razmotrenog primjera uspješne suradnje predstavnika dvaju susjednih naroda - Slovenca Matičetova i Hrvatice Radauš Ribarić treba reći da su ta dva naroda u interetničkim odnosima povijesno, kulturološki, politički i ekonomski, a svakako i profesionalno, bila upućena jedan na drugi u stoljetnom razdoblju koje smo u studenome 2017. godine obilježili prigodnim skupom i proslavom. Tijekom nekoliko stoljeća dva su se naroda nalazila u sklopu zajedničkih država, a od srpnja 2013. u najnovijoj asocijaciji Europske unije. U njoj i Slovenija i Hrvatska, uz današnji tipičan tranzicijski identitet uronjen u bespoštedne procese globalizacije, manje-više dijele sličnu sudbinu - podložne su prilagođavanju zahtjevima i željama financijera koji raspršuju temeljna istraživanja i usmjerenja discipline. Suradnja i umreženje Slovenije i Hrvatske ne bi samo olakšali prijenos informacija i znanja o aktualnim istraživanjima i rezultatima pojedinaca i projekata s obje strane nego bi pripomogli lakšem suočavanju sa spomenutim problemima. Valja se nadati da će smjernice zajedničkih stručnih i akademskih stremljenja krenuti plodonosno prema zajedničkom cilju. Hrvatsko-slovenska suradnja bremenita izazovima i na obredno-mitološkom području urodila je, i dalje rađa, zrelim plodovima.

\footnotetext{
59 Usp. bilj. 15.

60 Osim nekih starijih autora, posebno treba istaknuti odlučujući doprinos šezdesetih godina prošlog stoljeća dvojice ruskih indoeuropeista - Vjačeslava Vsevolodoviča Ivanova i Vladimira Nikolajeviča Toporova - koji se u to doba još ne spominju u slovenskoj i hrvatskoj znanstvenoj literaturi.
} 


\section{LITERATURA}

BAJUK, Lidija. 1999. Kneja. Zagreb: Mozaik knjiga.

BELAJ, Vitomir. 1995. "Blaženi Augustin Kažotić u pučkoj predaji". U Zagrebačka biskupija i Zagreb 1094-1994. Zbornik u čast kardinala Franje Kuharića, ur. Antun Škvorčević. Zagreb: Nadbiskupija zagrebačka, 403-412.

BELAJ, Vitomir. 1998. Hod kroz godinu. Mitska pozadina hrvatskih narodnih običaja i vjerovanja. Zagreb: Golden marketing.

BELAJ, Vitomir. 2007. Hod kroz godinu. Pokušaj rekonstrukcije prahrvatskoga mitskog svjetonazora. 2. izmijenjeno i dopunjeno izd. Zagreb: Golden marketing Tehnička knjiga.

ČAJKANOVIĆ, Veselin. 1973. Mit i religija u Srba: izabrane studije. Beograd: Srpska književna zadruga.

ČAJKANOVIĆ, Veselin. 1985. Rečnik srpskih narodnih verovanja o biljkama. Beograd: Srpska književna zadruga, Srpska akademija nauka i umetnosti.

FUČIĆ, Branko. 1962. "Sveti Juraj i Zeleni Juraj”. Zbornik za narodni život i običaje, knj. 40:129-150.

FUČIĆ, Branko. 1982. Glagoljski natpisi. Djela JAZU, knj. 57. JAZU: Zagreb.

GAVAZZI, Milovan. 1988 [1939]. Godina dana hrvatskih narodnih običaja. Zagreb: Kulturnoprosvjetni Sabor Hrvatske.

GERM, Tine. 2002. Simbolika cvetja. Ljubljana: Mladinska knjiga.

GRBIĆ, Jadranka. 2012. "Voda u vjerovanjima, običajima i ritualima. Analiza primjera iz hrvatske etnografske literature". Gazophylacium: časopis za znanost, umjetnost, gospodarstvo i politiku, vol. 17/1-2 [Voda u hrvatskom filološkom, povijesnom, etnografskom, heraldičkom i vodno-gospodarstvenom obzorju I.]:45-78.

HROBAT, Katja. 2010. Ko Baba dvigne krilo. Prostor in čas v folklori Krasa. Ljubljana: Univerza v Ljubljani - Filozofska fakulteta.

HROBAT VIRLOGET, Katja. 2013. "The Snooty Baba in the Landscape of Karst, Slovenia: About a Slavic Ambivalent Female Mythical Figure". Cosmos, vol. 29:141-171.

HROBAT VIRLOGET, Katja. 2015. "Mythical tradition in the stone: The snooty Babas as elements of rites of passage and soical control. U Stone Narratives - Heritage, Mobility, Performance, ed. Katja Hrobat Virloget, Irena Weber, Daša Fabjan i Andrej Preložnik. Koper: Založba Univerze na Primorskem, 55-64.

HROBAT VIRLOGET, Katja i Petra KAVREČIČ. 2015. "Mitska krajina Goropade v okviru ustnega izročila na Krasu in širše". U Nesnovna krajina Krasa, ur. Katja Hrobat Virloget i Petra Kavrečič. Koper: Založba Univerze na Primorskem, 69-84.

HUZJAK, Višnja. 1957. Zeleni Juraj. Publikacije Etnološkog seminara Filozofskog fakulteta Sveučilišta u Zagrebu, knj. 2. Zagreb: Filozofski fakultet Zagreb.

ISTARSKA ENCIKLOPEDIJA. 2005. Ur. Miroslav Bertoša i Robert Matijašić. Zagreb: Leksikografski zavod Miroslav Krleža. 
IVANOV, Vjačeslav Vsevolodovič i Vladimir Nikolajevič TOPOROV. 1974. Issledovanija v oblasti slavjanskih drevnostej: (Leksičeskie i frazeologičeskie voprosi rekonstrukcii tekstov). Moskva: Nauka.

JAKOVLJEVIĆ, Božo. 2001. "Iz prošlosti Lanišća, Vodica i Račje vasi”. Buzetski zbornik, vol. 27:261-273

JURIŠEVIĆ, Josip. 1939a. "Vodice u Ćićariji". Istra, god. XI, br. 40:4.

JURIŠEVIĆ, Josip. 1939b. "Molitva za kišu - Prastari narodni običaj u Vodicama". Istra, god. XI, br. 43:2.

KAJKOWSKI, Kamil i Andrzej KUCZKOWSKI. 2017. "Water in pre-Christian beliefs in Pomerania (northern Poland) of the early medieval period". Studia mythologica Slavica, vol. 20:15-32. DOI: https://doi.org/10.3986/sms.v20i0.6638

KATIČIĆ, Radoslav. 1987. "Hoditi-roditi: Spuren der Texte eines urslawischen Fruchtbarkeitsritus". Wiener Slavistisches Jahrbuch, vol. 33:23-43.

KATIČIĆ, Radoslav. 2010. Zeleni lug. Tragovima svetih pjesama naše pretkršćanske starine. Zagreb: Ibis grafika, Matica hrvatska - Mošćenička Draga: Katedra Čakavskog sabora.

KATIČIĆ, Radoslav. 2011. Gazdarica na vratima. Tragovima svetih pjesama naše pretkršćanske starine. Zagreb: Ibis grafika, Matica hrvatska - Mošćenička Draga: Katedra Čakavskog sabora.

KIPRE, Ivica. 2014. U stabru ti ljuti zmaje, u granam' ti soko sivi. Tragom pretkršćanskih elemenata u tradicijskoj kulturi dubrovačke okolice. Dubrovnik: Dubrovački muzeji - Etnografski muzeji.

KLEN, Danilo. 1960. "Fragmenti rašporskog urbara iz prve polovine XV stoljeća". Jadranski zbornik, vol. IV:155-182.

KROPEJ, Monika. 2013. "Istrian folk narrative tradition from the perspective of changing borders". Traditiones, vol. 42/1-2:187-200. DOI: https://doi.org/10.3986/Traditio2013420111

KURET, Niko. 1965. Praznično leto Slovencev I., Proljeće. Starosvetne šege in navade od pomladi do zime. Celje: Mohorjeva družba.

KURET, Niko. 1970. Praznično leto Slovencev IV., Zima. Starosvetne šege in navade od pomladi do zime. Celje: Mohorjeva družba.

MATIČETOV, Milko. 1977. Pet pisama naslovljenih Jelki Radauš Ribarić (20. srpnja, 19. kolovoza, 13. rujna, 18. listopada, 19. listopada 1977. godine). Pisma pronađena 1917. godine u ostavštini J. Radauš Ribarić.

MATIČETOV, Milko. 1979. "BEDENÍCE - Imena, pesniško in obredno izročilo o tem cvetju na Slovenskem in pri sosedih v hrvaški Istri". Traditiones - Acta Instituti ethnographiae Slovenorum, vol. 5-6(1976-1977):277-300.

NOVAK, Marija. 2007. Tragovi hrvatske mitologije. Zagreb: Institut za etnologiju i folkloristiku. RIBARIĆ, Josip. 1940. "Razmještaj južnoslavenskih dijalekata na poluotoku Istri". Srpski dijalektološki zbornik, vol. IX:1-207. http://dais.sanu.ac.rs/123456789/5996

RIBARIĆ, Josip. 2002. O istarskim dijalektima. Razmještaj južnoslavenskih dijalekata na 
poluotoku Istri s opisom vodičkog govora. Pazin: Josip Turčinović.

RADAUŠ RIBARIĆ, Jelka. 1977. Četiri pisma naslovljena Milku Matičetovu (24. lipnja,

18. kolovoza, 17. listopada, 24. listopada 1977. godine). Pisma pronađena 1917. godine u ostavštini J. Radauš Ribarić.

RADAUŠ RIBARIĆ, Jelka. 1991. "Životni put prof. Josipa Ribarića". Buzetski zbornik, vol. 16:5-19.

SKOK, Petar. 1973. Etimologijski rječnik hrvatskoga ili srpskoga jezika. Ur. M. Deanović i

Lj. Jonke. Knj. III. Zagreb: JAZU.

"Slum - najstarije drvo u Istri?". 2008. Izleti po Istri i okolici, http://izletipoistri.com,

27. 9. http://izletipoistri.com/2008/09/27/slum-najstarije-drvo-u-istri/

(pristup 17. 1. 2019.)

STIPANČEVIĆ, Mario. 2005. "Korespondencija Milovana Gavazzija u Hrvatskom državnom arhivu". Arhivski vjesnik, vol. 48:55-68. https://hrcak.srce.hr/7067

ŠANTEK, Goran Pavel. 2018. "Zeleni Juraj i hrvatska tradicijska kultura". U Tragovi tradicije, znakovi kulture. Zbornik u čast Stipi Botici, ur. Evelina Rudan, Davor Nikolić i Josipa Tomašić. Zagreb: Hrvatska sveučilišna naklada, Hrvatsko filološko društvo, Matica hrvatska, 465-476.

ŠMITEK, Zmago. 2011. Mitološko izročilo Slovencev. Svetinje preteklosti. Ljubljana: Študentska založba.

ŠULEK, Bogoslav. 1878. "Zašto Slaveni poštuju lipu". Rad JAZU, knj. 43:149-188. VINCE PALLUA, Jelka. 1995/1996. "History and Legend in Stone - to Kiss the Baba". Studia ethnologica Croatica, vol. 7-8:281-292. https://hrcak.srce.hr/59872

VINCE PALLUA, Jelka. 2018. "A newly discovered figurative representation of the mythical Baba - 'Old Baba Vukoša' in St. Mary's church of Gračišće in Istria”. U Sacralization of Landscape and Sacred Places, ur. Juraj Belaj et al. Zagreb, 105-117.

\section{Making Gifts to Water in a Ritual-Mythological Interpretation: An Example of Croatian-Slovenian Professional Cooperation}

\section{Jelka Vince Pallua}

The first part of the article focuses on the collaboration on the topic of symbolism of and the words for daffodils between the Croatian scholar Dr Jelka Radauš Ribarić and her Slovenian colleague and friend Dr Milko Matičetov. Based on their correspondence from 1977, the paper examines their generationally conditioned, similar ethnological reflections. In the main body of the paper, titled "The new interpretation", the author develops a new ritual-mythological interpretation of customary spring-time practices 
involving daffodils, a water spring and a lime tree in the village of Vodice in northern Istria, Croatia. The former St. George's day's procession, preserved there in the form of children's folklore by the presentation of daffodils to the spring and to a bogič/god on the lime tree is interpreted as a reflection or a relic of a (proto)Slavic, pre-Christian rite. The names for daffodils - jurjevke and Marijine palčke/Maričice - are explained within the same interpretative context.

Keywords: ritual-mythological interpretation, Proto-Slavic mythology, lime tree, Christianization, St. George's day, Jarylo, St. George, Mara, making gifts to water, water spring, daffodils, Istria, Vodice, Slovenian-Croatian professional cooperation

\section{Darovanje vode v obredno-mitološki interpretaciji: primer slovensko- hrvaškega znanstvenega sodelovanja}

\section{Jelka Vince Pallua}

V prvem delu članka je predstavljen konkreten primer znanstvenega sodelovanja med hrvaško znanstvenico dr. Jelko Radauš Ribarić in njenim slovenskim kolegom in prijateljem, akademikom Milkom Matičetovim pri obravnavi imen in simbolike narcis (bedenic). Na podlagi odkritega dopisovanja iz leta 1977 so obravnavani njuni premisleki, zasnovani na enakih etnoloških usmeritvah tistega časa. V najobsežnejšem delu, naslovljenem »Nova interpretacija teme«, avtorica ponuja novo obredno-mitološko interpretacijo pomladnih šeg, povezanih z izvirom, lipo in narcisami v Vodicah v severni Istri. Nekdanji jurjevski obhod, ki je tam ohranjen v obliki otroške folklore v pomladnem darovanju vrelca narcisam in bogiča na lipi, je interpretiran kot odsev, ostanek (pra) slovanskega in hkrati tudi predkrščanskega obreda. Avtorica imenje za narcise - jurjevke in Marijine palčke/Maričice - pojasnjuje z enakim interpretativnim kontekstom.

Ključne besede: obredno-mitološka interpretacija, praslovanska mitologija, pokristjanjevanje, Jurjevo, Jarilo, Juraj, Mara, darovanje vode, vrelec, narcise (bedenice), lipa, Istra, Vodice, slovensko-hrvaško znanstveno sodelovanje

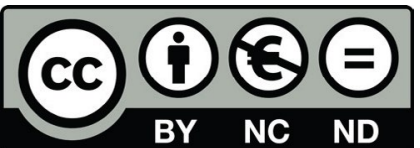

Articles published in this journal are Open Access and can be distributed under the terms and conditions of the Creative Commons license Attribution-NonCommercial-NoDerivatives 4.0 (http://creativecommons.org/licenses/by-nc-nd/4.0/) 